\title{
Granitoid plutons of the Brookville terrane, southern New Brunswick: petrology, age, and tectonic setting
}

\author{
Chris E. White ${ }^{1}$, Sandra M. Barr ${ }^{2}$, Brent V. Miller ${ }^{3}$, and Michael A. Hamilton ${ }^{4}$ \\ 1. Department of Natural Resources, P.O. Box 698, Halifax, Nova Scotia B3N 2T9 \\ 2. Department of Geology, Acadia University, Wolfville, Nova Scotia B4P 2R6 Canada \\ 3. Department of Geological Sciences, University of North Carolina, Chapel Hill, North Carolina, USA 27599-3315 \\ 4. Geological Survey of Canada, 601 Booth Street, Ottawa, Ontario K1A 0E8
}

Date received:August 27,2002 I Date accepted:December 12, 2002

\begin{abstract}
Latest Neoproterozoic and Cambrian plutons in the Brookville terrane of southern New Brunswick are termed the Golden Grove Plutonic Suite. Four groups are recognized on the basis of composition: gabbro (2 plutons), diorite - granodiorite (17 plutons), granodiorite - monzogranite (8 plutons), and syenogranite - monzogranite (7 plutons). The dioritic to granodioritic and most of the granodioritic to monzogranitic plutons form linear trends on chemical variation diagrams, suggesting that magma evolution was dominated by plagioclase and amphibole fractionation. These plutons appear to constitute a typical I-type, calc-alkaline suite characteristic of continental margin subduction zones. This interpretation is supported by U-Pb zircon ages, which show that these plutons have ages between $540 \mathrm{Ma}$ and 526 $\mathrm{Ma}$. A new U-Pb age of 539.6 $\pm 1.2 \mathrm{Ma}$ from one of the gabbroic plutons shows that the gabbroic plutons are co-genetic with the dioritic to granitic plutons, although they show varied ultramafic to anorthositic and dioritic compositions as a result of crystal accumulation. The syenogranitic to monzogranitic plutons and two of the granodioritic and monzogranitic plutons, as well as felsic volcanic rocks of the Dipper Harbour volcanic unit, show chemical trends that differ from the other plutons in having A-type characteristics. A U-Pb age of $548 \pm 2 \mathrm{Ma}$ for the Fairville Granite, as well as similar ages for a syenogranitic pluton and the Dipper Harbour volcanic unit, suggests that these units represent early stages of magmatism in the Golden Grove Plutonic Suite.
\end{abstract}

\section{RESUMÉ}

\begin{abstract}
Les plutons du Cambrien et des périodes les plus anciennes du Néoprotérozoïque à l'intérieur du terrane de Brookville dans le Sud du Nouveau-Brunswick sont désignés sous le nom de « cortège plutonique de Golden Grove ». On y distingue quatre groupes en fonction de leur composition : ceux à base de gabbro (deux plutons), de diorite - granodiorite (17 plutons), de granodiorite - monzogranite (huit plutons) et de syénogranite - monzogranite (sept plutons). Les plutons dioritiques à granodioritiques et la majorité des plutons granodioritiques à monzogranitiques forment des tracés linéaires sur les schémas de diversité de la composition chimique, ce qui laisse supposer que l'évolution magmatique a été dominée par une cristallisation fractionnée des plagioclases et des amphiboles. Ces plutons semblent constituer un cortège calco-alcalin intrusif typique, caractéristique des zones de subduction de la marge continentale. Cette interprétation est corroborée par la datation au U-Pb, obtenue à partir de zircon, qui révèle que ces plutons ont des âges entre $540 \mathrm{Ma}$ et $526 \mathrm{Ma}$. Une nouvelle datation au U-Pb obtenue à partir de zircon situant à 539,6 $\pm 1,2$ Ma l'âge de l'un des plutons gabbrö̈ques, signale que les plutons gabbroïques sont cogénétiques avec les plutons dioritiques à granitiques, même s'ils présentent des compositions ultramafiques à anorthositiques et dioritiques diversifiées par suite d'une accumulation de cristaux. Les plutons syénogranitiques à monzogranitiques et deux des plutons granodioritiques et monzogranitiques, de même que les roches volcanofelsiques de l'unité volcanique de Dipper Harbour, livrent des tracés chimiques différents des autres plutons du fait qu'ils possèdent les caractéristiques des plutons de type anorogénique. L'âge au U-Pb de $548 \pm 2 \mathrm{Ma}$ du granite de Fairville ainsi que les âges similaires d'un pluton syénogranitique et de l'unité volcanique de Dipper Harbour permettent de supposer que ces unités représentent les stades précoces du magmatisme à l'intérieur du cortège plutonique de Golden Grove.
\end{abstract}

\section{INTRODUCTION}

The Brookville terrane of southern New Brunswick (Fig. 1) consists of abundant gabbroic to granitic plutons intruded into Proterozoic gneissic, metasedimentary, and minor volcanic rocks (White 1996; White and Barr 1996; Eby and Currie 1996). White (1996) and White and Barr (1996) defined and described the petrological characteristics of 28 separate plutonic units in the terrane, most of which they interpreted to belong to a com- positionally expanded comagmatic I-type suite formed in a late Neoproterozoic to Cambrian continental margin subduction zone. The age interpretation was based on $\mathrm{U}-\mathrm{Pb}$ and ${ }^{40} \mathrm{Ar} /{ }^{39} \mathrm{Ar}$ dates that demonstrated latest Neoproterozoic and Cambrian ages for several plutons in the Saint John area. Eby and Currie (1996) presented petrological data for some of these plutons, and suggested links with plutons of similar ages in the Caledonia and New River terranes to the southeast and northwest, respectively (Fig. 1). 


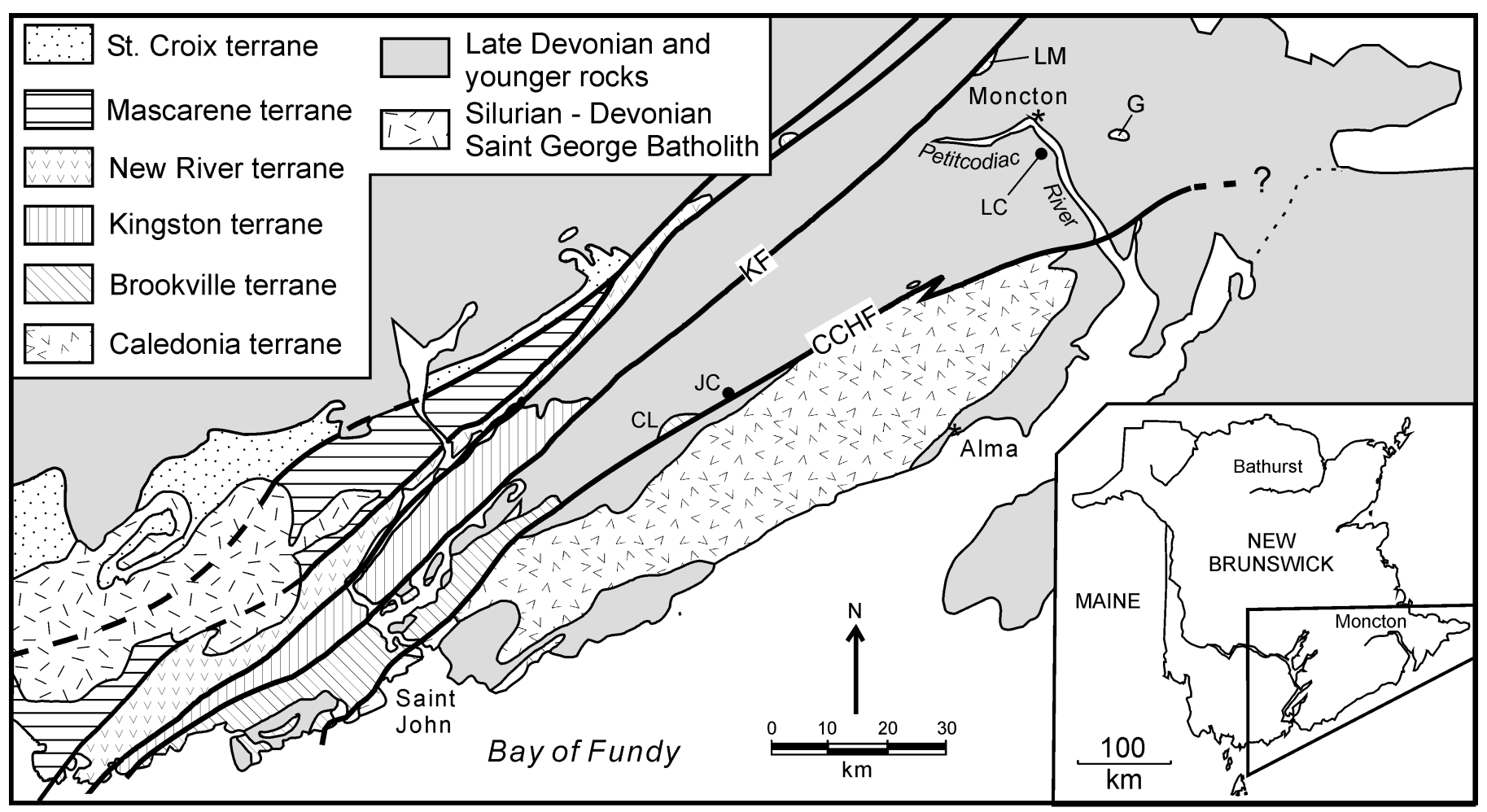

FIG. 1 Location of the Brookville and adjacent terranes in southern New Brunswick. Abbreviations: CCHF, Caledonia-Clover Hill Fault; CL, Cassidy Lake inlier; G, Gaytons Granite;JC, Jeffrey Corner inlier; KF, Kennebecasis Fault; LC, Lower Coverdale Gabbroic Complex (in subsurface); LM, Lutes Mountain.

The purpose of this paper is to present new and previously unpublished petrological and U-Pb geochronological data for plutons in the Brookville terrane. These new data show that the Neoproterozoic - Cambrian plutonic suite in the Brookville terrane also includes plutons in the Pocologan and Moncton areas, and that gabbroic plutons in the Saint John area, previously assumed to be younger (White and Barr 1996), are also part of this Neoproterozoic-Cambrian suite. In contrast, some plutons assumed to be part of the Neoproterozoic-Cambrian suite by White and Barr (1996) are now known to be younger (Barr et al. 2002a). Our new data, in combination with other recently published U-Pb ages (Currie and McNicoll 1999), provide additional constraints on the duration of plutonic activity in the Brookville terrane. We present a revised compilation of petrological features of Neoproterozoic and Cambrian plutons throughout the Brookville terrane, re-establish the name Golden Grove Plutonic Suite for these plutons, and further discuss their tectonic implications in the light of the new data.

\section{GEOLOGICAL SETTING}

The Brookville terrane is located between the Kennebecasis fault on the northwest and the Caledonia - Clover Hill fault on the southeast (Fig. 1). Rocks characteristic of the terrane outcrop mainly in the Saint John area, but have been traced to the northeast as far as the Moncton area on the basis of scattered outcrops and drill-hole intersections (White 1996). Metasedimentary rocks in the terrane are mainly assigned to the Green Head Group, which is divided into the two formations: Ashburn (dominantly marble with minor metaclastic rocks) and Martinon (dominantly metasiltstone with minor calc-silicate rocks, quartzite, conglomerate, and marble) (Fig. 2). These two formations have been interpreted to be lateral facies equivalents (White and Barr 1996). Based on locally preserved stromatolites, Hofmann (1974) suggested that the Green Head Group is Neohelikian (Mesoproterozoic) in age; more recent assessment suggested a minimum age of ca. $750 \mathrm{Ma}$ (H. Hofmann, written communication, 1991). The Green Head Group is in tectonic contact with the Brookville Gneiss, a locally migmatitic paragneiss with sheets of granodioritic to tonalitic orthogneiss, minor calc-silicate and marble layers, and rare quartzite and amphibolite layers. The paragneiss, which comprises about $75 \%$ of the Brookville Gneiss, contains detrital zircon indicating a maximum depositional age of ca. $640 \mathrm{Ma}$ (Bevier et al. 1990). The orthogneiss has an igneous crystallization age of $605 \pm 3 \mathrm{Ma}$, and was metamorphosed to amphibolite facies at $564 \pm 6 \mathrm{Ma}$ (Bevier et al. 1990; Dallmeyer et al. 1990). These dates indicate that the Brookville Gneiss is younger than the Green Head Group, but the original relationship between the two units remains problematic.

The Dipper Harbour volcanic unit is exposed in thrust sheets in the southern part of the terrane (Fig. 3). It includes felsic crystal and lithic tuff, flow-banded rhyolite, andesitic lithic tuff, laminated siltstone, and banded marble. A two-point $\mathrm{U}-\mathrm{Pb}$ age of ca. 555 Ma reported previously (Zain Eldeen 1991) for rhyolite in the Dipper Harbour unit has been confirmed by a new, more 
precise U-Pb (zircon) age of $552 \pm 3 \mathrm{Ma}$ (Barr et al. 2002a). The volcanic unit is associated spatially with syenogranitic plutons (Jarvies Lake, Cranberry Head, and Fishing Cove; Figs. 2, 3), and the U-Pb age is consistent with the imprecise $\mathrm{U}-\mathrm{Pb}$ (zircon) age of $550 \pm 15$ Ma reported for syenogranite in the nearby Musquash Harbour Pluton (Currie and Hunt 1991).

The units of the Brookville terrane contrast with those of the adjacent terranes in rock types and/or age (Barr and White 1996). The Caledonia terrane to the southeast (Fig. 1) consists of ca. 620 Ma and 560-550 Ma volcanic and sedimentary rocks intruded by plutons of similar ages, overlain by Cambrian sedimentary rocks (Barr and White 1999). The Kingston terrane to the northwest (Fig. 1) consists mainly of Silurian volcanic and epiclastic rocks and related granitic plutons (Barr et al. 2002c). A fault-bounded belt of partly mylonitic metasedimentary rocks termed the Pocologan metamorphic suite occurs between the Brookville and Kingston terranes in the southwest (Fig. 3), and has been linked to the Kingston terrane (Barr et al. 2002c).

\section{GOLDEN GROVE PLUTONIC SUITE}

Introduction

Plutons in the vicinity of the city of Saint John, as well as the Brookville Gneiss, were originally termed the "Golden Grove Intrusives" by Hayes and Howell (1937). The name was subsequently used to include plutons over a wider area in southern New Brunswick (e.g., Ruitenberg et al. 1979; Currie 1988). White et

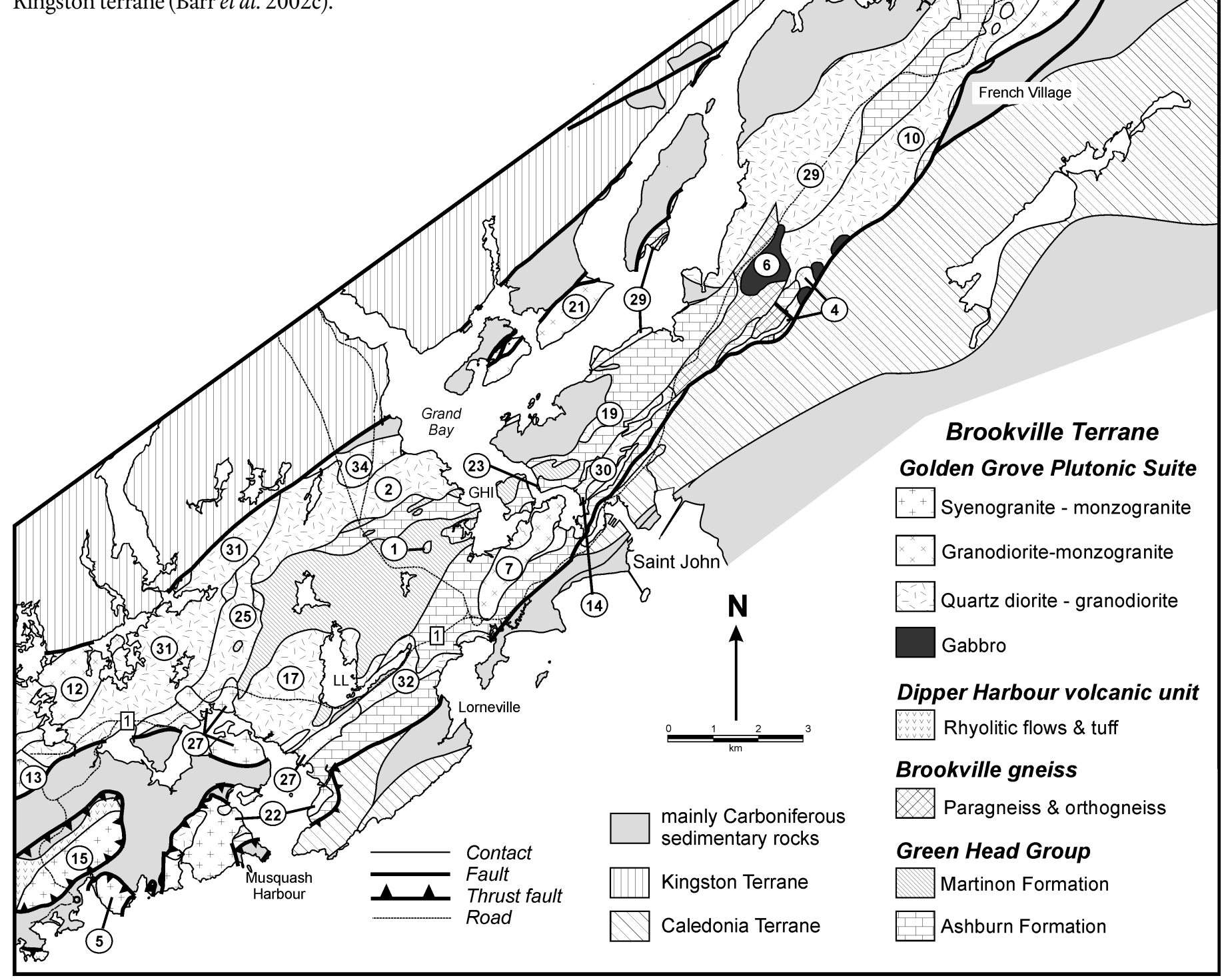

FIG. 2 Simplified geological map showing the distribution of major units in the central part of the Brookville terrane (Saint John area). Plutons are numbered - see Table 1 for names and brief descriptions. Abbreviations: GHI, Green Head Island; LL, Ludgate Lake. 
Table 1. Plutons of the redefined Golden Grove Plutonic Suite.

\begin{tabular}{|c|c|c|c|c|c|}
\hline & $\begin{array}{l}\text { Pluton and U-Pb age } \\
\text { [Ref\#] }\end{array}$ & General lithology & Texture & Contacts & Other field observations \\
\hline 1 & Acamac Tonalite & $\begin{array}{l}\text { dark grey to red, quartz } \\
\text { diorite to tonalite }\end{array}$ & $\begin{array}{l}\text { m.g. hypidiomorphic } \\
\text { equigranular }\end{array}$ & intrusive into Martinon Fm & similar to Mayflower Lake Tonalite. \\
\hline 2 & Belmont Tonalite & $\begin{array}{l}\text { light to dark grey tonalite } \\
\text { gradational to quartz } \\
\text { diorite and granodiorite }\end{array}$ & $\begin{array}{l}\text { m.g., allotriomorphic to } \\
\text { hypidiomorphic } \\
\text { equigranular; locally } \\
\text { inequigranular }\end{array}$ & $\begin{array}{l}\text { intrusive into Martinon Fm.; } \\
\text { intruded by Vairs Beach Granite }\end{array}$ & $\begin{array}{l}\text { xenoliths of marble, metasiltstone, quart- } \\
\text { zite; locally foliated; f.g. granite/aplite } \\
\text { dykes. }\end{array}$ \\
\hline 3 & $\begin{array}{l}\text { Carrying Cove } \\
\text { Granite }\end{array}$ & red biotite monzogranite & $\begin{array}{l}\text { m.g. hypidiomorphic } \\
\text { equigranular }\end{array}$ & $\begin{array}{l}\text { Occurs in a fault(?)-bounded } \\
\text { sliver in Carrying Cove area, } \\
\text { adjacent to Carboniferous } \\
\text { sedimentary rocks. }\end{array}$ & $\begin{array}{l}\text { lacks the large quartz crystals and abundant } \\
\text { dioritic xenoliths of the Hanson Stream } \\
\text { Granodiorite. Has more biotite (ca. 5\%) } \\
\text { than the Red Head Granite. }\end{array}$ \\
\hline 4 & Chalet Lake Granite & $\begin{array}{l}\text { orange monzogranite to } \\
\text { granodiorite }\end{array}$ & $\begin{array}{l}\text { c.g. hypidiomorphic } \\
\text { inequigranular }\end{array}$ & $\begin{array}{l}\text { poorly exposed; intrusive into } \\
\text { Ashburn Fm. }\end{array}$ & megacrysts of K-feldspar; tectonic foliation. \\
\hline 5 & $\begin{array}{l}\text { Cranberry Head } \\
\text { Syenogranite }\end{array}$ & $\begin{array}{l}\text { pink to maroon to orange } \\
\text { syenogranite to } \\
\text { monzogranite }\end{array}$ & $\begin{array}{l}\text { m.g. to c.g. hypidiomorphic } \\
\text { to allotrimorphic } \\
\text { equigranular to } \\
\text { inequigranular }\end{array}$ & thrust-faulted & $\begin{array}{l}\text { locally highly fractured and albitized; } \\
\text { leucocratic; granophyric; aplite veins } \\
\text { common. }\end{array}$ \\
\hline 6 & $\begin{array}{l}\text { Duck Lake Pluton } \\
539.6 \pm 1.2 \mathrm{Ma}[1]\end{array}$ & $\begin{array}{l}\text { black to white, gabbroic, } \\
\text { ultramafic, and } \\
\text { anorthositic rocks }\end{array}$ & $\begin{array}{l}\text { varied textured layered } \\
\text { intrusion }\end{array}$ & $\begin{array}{l}\text { poorly exposed; intrusive into } \\
\text { French Village pluton and } \\
\text { Brookville Gneiss }\end{array}$ & local pegmatoid lenses. \\
\hline 7 & $\begin{array}{l}\text { Fairville Granite } \\
548 \pm 2 \mathrm{Ma}[1]\end{array}$ & $\begin{array}{l}\text { pink to orange } \\
\text { monzogranite to } \\
\text { granodiorite }\end{array}$ & $\begin{array}{l}\text { c.g. hypidiomorphic } \\
\text { inequigranular }\end{array}$ & $\begin{array}{l}\text { strongly deformed southeast } \\
\text { contacts; intrusive into } \\
\text { Brookville Gneiss and Ashburn }\end{array}$ & $\begin{array}{l}\text { xenoliths of gneiss and marble; rare dioritic } \\
\text { enclaves; megacrysts of K-feldspar. }\end{array}$ \\
\hline 8 & $\begin{array}{l}\text { Fishing Point } \\
\text { Syenogranite }\end{array}$ & $\begin{array}{l}\text { similar to Cranberry Head } \\
\text { Syenogranite }\end{array}$ & $\begin{array}{l}\text { similar to Cranberry Head } \\
\text { Syenogranite }\end{array}$ & $\begin{array}{l}\text { faulted against Dipper Harbour } \\
\text { volcanic unit and Triassic rocks }\end{array}$ & $\begin{array}{l}\text { probably related to Cranberry Head } \\
\text { Syenogranite. }\end{array}$ \\
\hline 9 & $\begin{array}{l}\text { Foleys Cove } \\
\text { Granodiorite }\end{array}$ & $\begin{array}{l}\text { grey to red altered } \\
\text { granodiorite }\end{array}$ & $\begin{array}{l}\text { originally c.g. but now } \\
\text { sheared and deformed, with } \\
\text { mylonitic bands common; } \\
\text { relict granophyric texture } \\
\text { observed in one sample. }\end{array}$ & $\begin{array}{l}\text { faulted against Kingston terrane } \\
\text { to the north and McCarthy Point } \\
\text { Granodiorite to the south }\end{array}$ & $\begin{array}{l}\text { May also be present in the Pocologan } \\
\text { Harbour granitoid belt. Not well exposed. }\end{array}$ \\
\hline 10 & $\begin{array}{l}\text { French Village Quartz } \\
\text { Diorite } \\
537 \pm 2 \mathrm{Ma}[5]\end{array}$ & $\begin{array}{l}\text { dark grey to black, light } \\
\text { grey to white diorite to } \\
\text { tonalite }\end{array}$ & $\begin{array}{l}\text { m.g. to c.g., hypidiomorphic } \\
\text { equigranular to } \\
\text { inequigranular }\end{array}$ & $\begin{array}{l}\text { faulted contacts; intrusive into } \\
\text { Brookville Gneiss and Ashburn } \\
\text { Fm. }\end{array}$ & $\begin{array}{l}\text { xenoliths of marble, quartzite and gneiss; } \\
\text { dioritic enclaves; locally foliated and } \\
\text { porphyritic. }\end{array}$ \\
\hline 11 & $\begin{array}{l}\text { Hammond River } \\
\text { Granite }\end{array}$ & $\begin{array}{l}\text { pink to orange } \\
\text { monzogranite to } \\
\text { granodiorite }\end{array}$ & $\begin{array}{l}\text { f.g. to c.g. hypidiomorphic } \\
\text { equigranular to } \\
\text { inequigranular }\end{array}$ & $\begin{array}{l}\text { intrusive into Ashburn Fm. and } \\
\text { French Village pluton; } \\
\text { unconformably overlain by } \\
\text { Devonian to Carboniferous } \\
\text { sedimentary rocks }\end{array}$ & $\begin{array}{l}\text { xenoliths of marble, amphibolite, and } \\
\text { gneiss; rare elongate dioritic enclaves; } \\
\text { locally foliated; also exposed in Cassidy Lake } \\
\text { inlier (see Fig. 1) }\end{array}$ \\
\hline 12 & $\begin{array}{l}\text { Hanson Stream } \\
\text { Granodiorite } \\
528+1 /-3 \mathrm{Ma}[4]\end{array}$ & $\begin{array}{l}\text { grey to light grey } \\
\text { granodiorite to } \\
\text { monzogranite }\end{array}$ & $\begin{array}{l}\text { c.g. hypidiomorphic ineqi- } \\
\text { granular }\end{array}$ & $\begin{array}{l}\text { intrusive into Harvey Hill } \\
\text { Syenogranite }\end{array}$ & $\begin{array}{l}\text { small rounded dioritic to tonalitic enclaves; } \\
\text { phenocrysts of quartz; interstitial K- } \\
\text { feldspar; f.g. aplitic dykes. }\end{array}$ \\
\hline 13 & $\begin{array}{l}\text { Harvey Hill } \\
\text { Syenogranite } \\
544 \pm 4 \mathrm{Ma}[4]\end{array}$ & $\begin{array}{l}\text { pink to maroon } \\
\text { syenogranite }\end{array}$ & $\begin{array}{l}\text { f.g. allotrimorphic to } \\
\text { hypidiomorphic } \\
\text { inequigranular }\end{array}$ & surrounded by younger plutons & $\begin{array}{l}\text { leucocratic and granophyric; locally } \\
\text { subporphyritic; minor muscovite and rare } \\
\text { fluorite. }\end{array}$ \\
\hline 14 & Indiantown Pluton & $\begin{array}{l}\text { black to white } \\
\text { orthopyroxene gabbro, } \\
\text { anorthosite }\end{array}$ & $\begin{array}{l}\text { varied textured; layered } \\
\text { intrusion }\end{array}$ & poorly exposed & locally pegmatoid. \\
\hline 15 & $\begin{array}{l}\text { Jarvies Lake } \\
\text { Syenogranite }\end{array}$ & $\begin{array}{l}\text { pink to maroon to orange } \\
\text { syenogranite to } \\
\text { monzogranite }\end{array}$ & $\begin{array}{l}\text { m.g. to c.g. hypidiomorphic } \\
\text { to allotrimorphic } \\
\text { equigranular to equigranular }\end{array}$ & $\begin{array}{l}\text { thrust faulted; intrusive into } \\
\text { Dipper Harbour volcanic unit(?) }\end{array}$ & $\begin{array}{l}\text { leucocratic; granophyric; aplite veins } \\
\text { common. Probably related to Cranberry } \\
\text { Head Syenogranite. }\end{array}$ \\
\hline 16 & $\begin{array}{l}\text { Joshua Lake } \\
\text { Granodiorite }\end{array}$ & red granodiorite & $\begin{array}{l}\text { m.g. to c.g. hypidiomorphic } \\
\text { equigranular }\end{array}$ & $\begin{array}{l}\text { thin sliver in the Joshua Lake } \\
\text { area. }\end{array}$ & $\begin{array}{l}\text { Contains ca. } 20 \% \text { amphibole; becomes } \\
\text { coarser and more granitic to the SW }\end{array}$ \\
\hline 17 & $\begin{array}{l}\text { Ludgate Lake } \\
\text { Granodiorite } \\
546 \pm 2 \mathrm{Ma}[1]\end{array}$ & $\begin{array}{l}\text { grey to grey-green } \\
\text { granodiorite to tonalite }\end{array}$ & $\begin{array}{l}\text { f.g. to m.g., hypidiomorphic } \\
\text { equigranular }\end{array}$ & $\begin{array}{l}\text { intrusive into Martinon Fm. and } \\
\text { faulted against Spruce Lake } \\
\text { Pluton; locally intruded by } \\
\text { Prince of Wales Granite }\end{array}$ & $\begin{array}{l}\text { xenoliths of metasiltstone; enclaves of f.g. } \\
\text { diorite to tonalite; locally foliated; aplite } \\
\text { dykes }\end{array}$ \\
\hline 18 & $\begin{array}{l}\text { Lutes Mountain } \\
\text { Diorite } \\
542 \pm 1.5 \mathrm{Ma}[1]\end{array}$ & dark grey diorite & $\begin{array}{l}\text { m.g. hypidiomorphic } \\
\text { equigranular }\end{array}$ & $\begin{array}{l}\text { faulted sliver surrounded by } \\
\text { Carboniferous rocks }\end{array}$ & very altered and sheared. \\
\hline 19 & $\begin{array}{l}\text { Mayflower Lake } \\
\text { Tonalite }\end{array}$ & $\begin{array}{l}\text { dark grey to red, quartz } \\
\text { diorite to tonalite }\end{array}$ & $\begin{array}{l}\text { f.g. to m.g., hypidiomorphic } \\
\text { equigranular }\end{array}$ & $\begin{array}{l}\text { intrusive into Ashburn Fm.; } \\
\text { unconformably overlain by } \\
\text { Carboniferous sedimentary }\end{array}$ & $\begin{array}{l}\text { minor dioritic to tonalitic enclaves; similar } \\
\text { to the smaller Narrows and Acamac plutons }\end{array}$ \\
\hline
\end{tabular}


Table 1. (contd.)

\begin{tabular}{|c|c|c|c|c|c|}
\hline & $\begin{array}{l}\text { Pluton and U-Pb age } \\
{[\text { Ref \# }]}\end{array}$ & General lithology & Texture & Contacts & Other field observations \\
\hline 20 & $\begin{array}{l}\text { McCarthy Point } \\
\text { Granodiorite } \\
528+4 /-3 \mathrm{Ma}[3\rceil\end{array}$ & $\begin{array}{l}\text { grey to grey-green } \\
\text { granodiorite }\end{array}$ & $\begin{array}{l}\text { m.g. hypidiomorphic } \\
\text { granular, with subhedral } \\
\text { plagioclase grains }\end{array}$ & $\begin{array}{l}\text { well exposed, less altered to the } \\
\text { east; intruded by Penn Island } \\
\text { Granite. }\end{array}$ & $\begin{array}{l}\text { very deformed locally; also a major } \\
\text { component of the Pocologan Harbour } \\
\text { granitoid belt. }\end{array}$ \\
\hline 21 & Milkish Head Pluton & $\begin{array}{l}\text { pink to red monzogranite } \\
\text { to granodiorite }\end{array}$ & $\begin{array}{l}\text { c.g. hypidiomorphic } \\
\text { inequigranular monzogranite; } \\
\text { granodiorite tends to be more } \\
\text { m.g. and equigranular. }\end{array}$ & $\begin{array}{l}\text { faulted and locally mylonitic } \\
\text { along northern contact }\end{array}$ & $\begin{array}{l}\text { rare dioritic to tonalitic enclaves; large } \\
\text { phenocrysts of quartz common; f.g. granite } \\
\text { \& aplite dykes }\end{array}$ \\
\hline 22 & $\begin{array}{l}\text { Musquash Harbour } \\
\text { Pluton } \\
550 \pm 15 \mathrm{Ma}[2]\end{array}$ & $\begin{array}{l}\text { pink monzogranite to } \\
\text { syenogranite; grey-green } \\
\text { granodiorite to quartz } \\
\text { diorite }\end{array}$ & $\begin{array}{l}\text { m.g. to c.g., hypidiomorphic } \\
\text { inequigranular to } \\
\text { equigranular }\end{array}$ & $\begin{array}{l}\text { faulted contacts; intrusive into } \\
\text { Ashburn Fm.; unconformably } \\
\text { overlain by Carboniferous } \\
\text { limestone }\end{array}$ & $\begin{array}{l}\text { composite pluton; syenogranite } \\
\text { granophyric; f.g. granite/aplite dykes in } \\
\text { granodiorite to quartz diorite parts. }\end{array}$ \\
\hline 23 & Narrows Tonalite & $\begin{array}{l}\text { dark grey to red, quartz } \\
\text { diorite to tonalite }\end{array}$ & $\begin{array}{l}\text { f.g. to m.g., hypidiomorphic } \\
\text { equigranular }\end{array}$ & $\begin{array}{l}\text { not exposed; intrusive into } \\
\text { Ashburn Fm.? }\end{array}$ & similar to Mayflower Lake Tonalite. \\
\hline 24 & Penn Island Granite & $\begin{array}{l}\text { grey to pink } \\
\text { monzogranite }\end{array}$ & $\begin{array}{l}\text { m.g. to c.g. hypidiomorphic } \\
\text { equigranular }\end{array}$ & $\begin{array}{l}\text { intrusive into McCarthy Point } \\
\text { Granodiorite. }\end{array}$ & $\begin{array}{l}\text { also a component of the Pocologan Harbour } \\
\text { graniotid belt. }\end{array}$ \\
\hline 25 & $\begin{array}{l}\text { Perch Lake } \\
\text { Granodiorite }\end{array}$ & $\begin{array}{l}\text { light to dark grey } \\
\text { granodiorite }\end{array}$ & $\begin{array}{l}\text { m.g., hypidiomorphic } \\
\text { equigranular to } \\
\text { inequigranular }\end{array}$ & $\begin{array}{l}\text { intrusive into Martinon Fm.; } \\
\text { intruded by Prince of Wales } \\
\text { Granite }\end{array}$ & $\begin{array}{l}\text { dioritic to tonalitic enclaves; foliated near } \\
\text { contacts with Martinon Fm. }\end{array}$ \\
\hline 26 & $\begin{array}{l}\text { Pocologan Harbour } \\
\text { granitoid belt }\end{array}$ & $\begin{array}{l}\text { protolylonitic to mylonitic } \\
\text { granodiorite, granite, } \\
\text { diorite }\end{array}$ & $\begin{array}{l}\text { little original granitoid } \\
\text { mineralogy or texture } \\
\text { preserved. Contains } \\
\text { muscovite, epidote, minor } \\
\text { biotite, no amphibole; quartz } \\
\text { ribbons, highly saussuritized } \\
\text { nlagioclase: minor K-feldsnar. }\end{array}$ & $\begin{array}{l}\text { faulted against the Pocologan } \\
\text { metamorphic suite to the north } \\
\text { and mainly McCarthy Point } \\
\text { Granodiorite to the south. }\end{array}$ & $\begin{array}{l}\text { a mixture of McCarthy Point Granodiorite, } \\
\text { Penn Island Granite, Foleys Cove } \\
\text { Granodiorite, and more dioritic rocks. }\end{array}$ \\
\hline 27 & $\begin{array}{l}\text { Prince of Wales } \\
\text { Granite }\end{array}$ & $\begin{array}{l}\text { pink monzogranite to } \\
\text { syenogranite }\end{array}$ & $\begin{array}{l}\text { m.g., allotrimorphic to } \\
\text { hypidiomorphic equigranular } \\
\text { to inequigranular }\end{array}$ & $\begin{array}{l}\text { locally faulted; intrusive into } \\
\text { Perch Lake, Ludgate Lake, and } \\
\text { Spruce Lake plutons }\end{array}$ & $\begin{array}{l}\text { locally tectonic foliation; leucocratic and } \\
\text { granophyric. }\end{array}$ \\
\hline 28 & Red Head Granite & red granite & $\begin{array}{l}\text { c.g. allotriomorphic } \\
\text { equigranular }\end{array}$ & $\begin{array}{l}\text { faulted contact with McCarthy } \\
\text { Point Granodiorite }\end{array}$ & $\begin{array}{l}\text { no chemical data. Could be related to the } \\
\text { syenogranitic plutons. }\end{array}$ \\
\hline 29 & Renforth Pluton & $\begin{array}{l}\text { dark grey to red, quartz } \\
\text { diorite to tonalite, locally } \\
\text { granodioritic }\end{array}$ & $\begin{array}{l}\text { f.g. to m.g., hypidiomorphic } \\
\text { equigranular; locally } \\
\text { allotrimorphic inequigranular }\end{array}$ & $\begin{array}{l}\text { intrusive into Ashburn Fm. and } \\
\text { French Village pluton; } \\
\text { unconformably overlain by } \\
\text { Carboniferous sedimentary rocks }\end{array}$ & $\begin{array}{l}\text { minor dioritic to tonalitic enclaves; locally } \\
\text { porphyritic; locally mineralized along shear } \\
\text { zones. }\end{array}$ \\
\hline 30 & $\begin{array}{l}\text { Rockwood Park } \\
\text { Granodiorite } \\
538 \pm 1 \mathrm{Ma}[2]\end{array}$ & $\begin{array}{l}\text { grey tonalite to } \\
\text { granodiorite }\end{array}$ & $\begin{array}{l}\text { m.g. foliated, hypidiomorphic } \\
\text { equigranular }\end{array}$ & $\begin{array}{l}\text { poorly exposed; intrusive into } \\
\text { Ashburn Fm. }\end{array}$ & $\begin{array}{l}\text { forms two bodies; elongate dioritic to } \\
\text { tonalitic enclaves. }\end{array}$ \\
\hline 31 & $\begin{array}{l}\text { Shadow Lake } \\
\text { Granodiorite }\end{array}$ & $\begin{array}{l}\text { grey granodiorite to } \\
\text { tonalite }\end{array}$ & $\begin{array}{l}\text { m.g. to c.g., hypidiomorphic } \\
\text { to allotrimorphic } \\
\text { inequigranular }\end{array}$ & $\begin{array}{l}\text { poorly exposed or faulted; sharp } \\
\text { contact with Hanson Stream } \\
\text { pluton and intruded by Harvey } \\
\text { Hill pluton }\end{array}$ & $\begin{array}{l}\text { elongate dioritic to tonalitic enclaves; } \\
\text { magma mixing/mingling textures; locally } \\
\text { foliated. }\end{array}$ \\
\hline 32 & Spruce Lake Pluton & $\begin{array}{l}\text { light grey to black quartz } \\
\text { diorite to tonalite; minor } \\
\text { granodiorite }\end{array}$ & $\begin{array}{l}\text { m.g. to c.g., hypidiomorphic } \\
\text { equigranular to } \\
\text { inequigranular }\end{array}$ & $\begin{array}{l}\text { generally faulted; intrusive into } \\
\text { Ashburn Fm. and intruded by } \\
\text { Prince of Wales Granite }\end{array}$ & $\begin{array}{l}\text { xenoliths of metasiltstone and marble; } \\
\text { dioritic enclaves; locally foliated }\end{array}$ \\
\hline 33 & $\begin{array}{l}\text { Talbot Road } \\
\text { Granodiorite }\end{array}$ & $\begin{array}{l}\text { grey to pink granodiorite } \\
\text { to tonalite }\end{array}$ & $\begin{array}{l}\text { f.g. to m.g. hypidiomorphic } \\
\text { equigranular to locally } \\
\text { inequigranular }\end{array}$ & poorly exposed; locally faulted & $\begin{array}{l}\text { forms two bodies; dioritic to tonalitic } \\
\text { enclaves; locally foliated; f.g. granite/aplite } \\
\text { dykes }\end{array}$ \\
\hline 34 & Vairs Beach Granite & $\begin{array}{l}\text { red to orange } \\
\text { monzogranite to } \\
\text { granodiorite }\end{array}$ & $\begin{array}{l}\text { m.g. to c.g. hypidiomorphic } \\
\text { to allotrimorphic } \\
\text { equigranular }\end{array}$ & $\begin{array}{l}\text { northern contact faulted; } \\
\text { intrusive into Belmont pluton; } \\
\text { unconformably overlain by } \\
\text { Carboniferous sedimentary rocks }\end{array}$ & $\begin{array}{l}\text { leucocratic and granophyric; xenoliths of } \\
\text { marble and metasiltstone }\end{array}$ \\
\hline
\end{tabular}

References:

1 This paper

2 White et al. (1990)

3 Currie and Hunt (1991)

4 Currie and McNicoll (1999)

5 Bevier et al. (1991) 


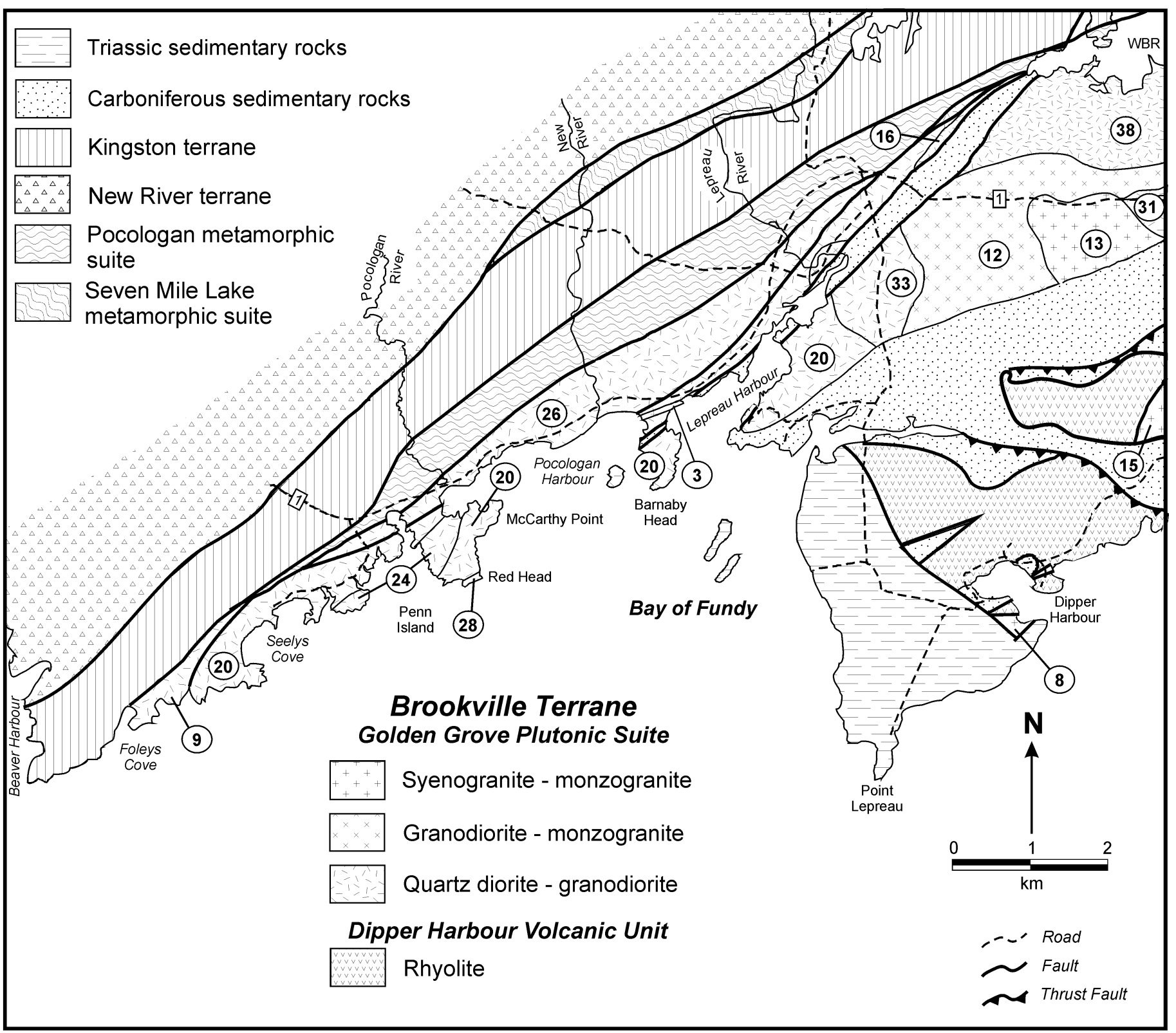

FIG. 3 Simplified geological map showing the distribution of major units in the southwestern (Pocologan) part of the Brookville terrane. Plutons are numbered-see Table 1 for names and brief descriptions.

al. (1990) suggested that the term Golden Grove Intrusive Suite should be abandoned because the rocks assigned to it are not all plutonic, are not all the same age, and do not belong to a single intrusive suite. However, in recognition that a collective name is needed for plutons in the Brookville terrane, Barr et al. (2001) suggested that the name Golden Grove Plutonic Suite be redefined to refer only to the latest Neoproterozoic to Cambrian gabbroic to granitic plutons of the Brookville terrane, a recommendation followed here.

The 34 plutons that comprise the redefined Golden Grove Plutonic Suite are listed in Table 1. They include most plutons known in the Brookville terrane; exceptions are orthogneissic components of the Brookville Gneiss, the Gaytons Granite, and subsurface gabbroic, anorthositic, and granitic rocks of the Lower Coverdale Gabbroic Complex. These units are excluded because
$\mathrm{U}-\mathrm{Pb}$ data indicate an older, ca. $605 \mathrm{Ma}$, age for the Brookville orthogneiss, as noted above, and a Devonian age for the Gaytons Granite and the Lower Coverdale complex (Barr et al. 2002a). Although not all plutons of the re-defined Golden Grove Plutonic Suite have been dated, a latest Neoproterozoic to Cambrian age is assumed on the basis of petrological similarities to dated plutons. Some pluton names have been changed from those used by White (1996) and White and Barr (1996) because of conflicts with preexisting unit names (L.R. Fyffe, personal communication, 2000), or because additional work clarified their inclusion in other units (Barr et al. 2001). Some plutons have been added as a result of additional work in the Pocologan and Lutes Mountain area, as described below. Because a variety of different names have been used in the past for some of these plutons, White (1996) provided, for clarification, a compilation of the previous terminology rela- 
tive to current usage. Detailed maps that include the plutons in the Saint John and Pocologan areas have been published (Barr and White 2001); simplified maps are shown in Figures 2 and 3.

\section{Composition}

The plutons of the Golden Grove suite can be broadly grouped into four compositional types depending on the dominant rock type, abundance of mafic minerals, and texture: (1) gabbro, (2) diorite to granodiorite, (3) granodiorite to monzogranite, and (4) syenogranite to monzogranite. As summarized in Table 1, relative ages among some plutons of the suite can be established based on cross-cutting relationships and/or the presence of xenoliths. These observations do not suggest a clear sequence of intrusive relationships from mafic to felsic. The lack of a compositional pattern is supported also by the U-Pb ages (see below) in those cases where the ages are precise enough to indicate an order of intrusion. However, the close spatial association of the plutons suggests that they were generated in the same place at more or less the same time by more or less the same processes, but that magma evolution was parallel, as well as sequential. Such complex "compositionally expanded series" are typical of Andean-type subduction zones (e.g., Pitcher 1994).

\section{Gabbroic plutons}

Two small gabbroic plutons, Duck Lake and Indiantown (Fig. 2), are part of the Golden Grove Plutonic Suite. The Duck Lake Pluton has an area of about $1.5 \mathrm{~km}^{2}$, and mainly intruded the Brookville Gneiss. However, its eastern margin is an inferred intrusive contact with the Renforth and French Village plutons (Fig. 2), consistent with its slightly younger U-Pb age (see below and Table 1). Rock types sampled in the Duck Lake Pluton include gabbro, orthopyroxene gabbro, gabbronorite, olivine gabbronorite, anorthosite, dunite, and wehrlite (Grammatikopoulos 1992; White 1996). The smaller Indiantown body, less than 0.5 $\mathrm{km}^{2}$ in area, consists of orthopyroxene gabbro and anorthosite, surrounded by rocks of the French Village Quartz Diorite (Fig. 2). Smaller, probably related, gabbroic bodies also occur in the area of the Duck Lake Pluton (Fig. 2), and it is probable that some of the mafic dykes that occur widely in units of the Brookville terrane are also related to these gabbroic bodies.

White (1996) interpreted the Duck Lake and Indiantown plutons, as well as the Lower Coverdale Gabbroic Complex southwest of Moncton (Fig. 1), to be younger than other plutons in the Brookville terrane. He suggested a Silurian age, because Silurian gabbroic bodies occur elsewhere in southern New Brunswick and Maine (West et al. 1992), and in central Cape Breton Island (Keppie et al. 2000). However, the U-Pb age presented here demonstrates that the Duck Lake Pluton is the same age as the intermediate and felsic plutons described below, and hence it is here included in the Golden Grove Plutonic Suite. The Indiantown Pluton is similar in petrology to the Duck Lake pluton, and is likely of similar age. In contrast, the Lower Coverdale Gabbroic Complex is not included in the Golden Grove suite because of its probable Devonian age (Barr et al. 2002b).

\section{Dioritic to granodioritic plutons}

Dioritic to granodioritic plutons are the largest and most abundant in the Brookville terrane at the present level of exposure (Figs. 2, 3). They are generally elongate northeast-southwest, parallel to the terrane margins. These plutons are named according to their most abundant rock type, but most show a wide range in composition. Most also contain abundant dioritic to tonalitic enclaves, which may represent cognate material formed at earlier stages of crystallization from the same magma as the host. Locally, they display evidence of magma mingling and mixing between enclaves and host, and in these cases the enclaves may represent blebs of immiscible, more mafic melt in the host magma (e.g., Barbarin and Didier 1992). Locally, enclaves are elongate parallel to the long axis of the intrusion, suggestive of a flow fabric.

In addition to the plutons described in detail by White (1996), the dioritic to granodioritic group also includes the Lutes Mountain Diorite (Fig. 1) and most plutons in the Pocologan Harbour area (Fig. 3), as described by Barr et al. (2001). The former Lepreau Harbour and Lepreau plutons of White (1996) and White and Barr (1996) are now considered part of the McCarthy Point Granodiorite and Pocologan Harbour granitoid belt, respectively. The Pocologan Harbour granitoid belt is an informal name for a mixture of highly deformed rocks in which recognition of protoliths and subdivision is difficult due to the extent of deformation. This belt coincides approximately with the Pocologan mylonite zone of earlier workers (e.g. Park et al. 1994).

The dioritic to granodioritic plutons are typically medium grained, with more than $20 \%$ combined hornblende and biotite. Zoned plagioclase with average composition of andesine is the most abundant mineral, with less abundant interstitial K-feldspar and quartz. Amphibole is typically second in abundance to plagioclase, and is mainly calcic amphibole of magnesio-hornblende composition (White 1996). Remnant clinopyroxene cores were observed rarely in amphibole in the most mafic plutons and their enclaves. Biotite is generally less abundant than amphibole, has $\mathrm{Fe} / \mathrm{Mg}$ ratio intermediate between phlogopite and annite end members, and overall composition typical of biotite in calc-alkalic plutons (Abdel-Rahman 1994). The most abundant accessory minerals are magnetite and titanite.

\section{Granodioritic to monzogranitic plutons}

Plutons of granodioritic and monzogranitic composition are less abundant and typically smaller than those of the dioritic to granodioritic group. They also show less range in composition, and are generally composed of granodiorite and/or monzogranite and minor syenogranite. These plutons are typically coarse grained, and contain less than $10 \%$ amphibole and biotite. Mafic xenoliths are not generally abundant, except in the Hanson Stream Granodiorite (\#12, Table 1), which is characterized by abundant small dioritic xenoliths and prominent large quartz grains. Similar large quartz grains occur locally in the Penn Island and Milkish Head plutons. The Hammond River Granite forms the northeastern part of the terrane and appears to grade from granodiorite to monzogranite and locally syenogranite 
Table 2. New chemical data from plutons of the Golden Grove Plutonic Suite.

\begin{tabular}{|c|c|c|c|c|c|c|c|c|c|c|c|c|c|c|}
\hline Pluton \# & 3 & 9 & 9 & 16 & 18 & 20 & 20 & 20 & 20 & 20 & 20 & 20 & 20 & 24 \\
\hline Sample & NB00-105 & K99-516 & K99-517 & K99-472 & NB00-11 & K99-482A & K99-487A & K99-518A & K99-522A & NB00-104 & NB00-112 & NB00-43A & NB99-5 & K99-519 \\
\hline Easting & 701400 & 682800 & 683350 & 703200 & 355450 & 687750 & 700450 & 683600 & 689200 & 700900 & 689750 & 695050 & 690750 & 686650 \\
\hline Northing & 5000750 & 4993400 & 4993600 & 5009150 & 5113950 & 4997300 & 4906700 & 4993400 & 4996600 & 5007150 & 4998150 & 4998800 & 4998450 & 4995800 \\
\hline \multicolumn{15}{|c|}{ Major elements (wt. \%) } \\
\hline $\mathrm{SiO}_{2}$ & 75.64 & 68.66 & 66.33 & 62.85 & 56.73 & 65.18 & 57.01 & 66.28 & 60.33 & 55.13 & 64.01 & 65.29 & 59.43 & 68.98 \\
\hline $\mathrm{TiO}_{2}$ & 0.24 & 0.31 & 0.36 & 0.71 & 0.71 & 0.37 & 1.19 & 0.38 & 0.46 & 1.20 & 0.40 & 0.66 & 0.48 & 0.30 \\
\hline $\mathrm{Al}_{2} \mathrm{O}_{3}$ & 12.66 & 14.22 & 15.65 & 16.49 & 16.19 & 16.09 & 17.12 & 15.53 & 17.25 & 17.23 & 16.02 & 15.47 & 17.94 & 15.19 \\
\hline $\mathrm{Fe}_{2} \mathrm{O}_{3}{ }^{\mathrm{t}}$ & 1.15 & 3.20 & 3.75 & 4.74 & 6.21 & 4.27 & 7.18 & 3.93 & 5.39 & 7.61 & 4.59 & 4.68 & 6.12 & 3.14 \\
\hline $\mathrm{MnO}$ & 0.06 & 0.07 & 0.06 & 0.10 & 0.12 & 0.08 & 0.13 & 0.07 & 0.09 & 0.14 & 0.08 & 0.09 & 0.11 & 0.07 \\
\hline $\mathrm{MgO}$ & 0.27 & 1.31 & 1.87 & 2.06 & 4.08 & 1.99 & 2.98 & 2.07 & 2.89 & 3.28 & 2.48 & 2.07 & 3.15 & 1.67 \\
\hline $\mathrm{CaO}$ & 0.89 & 1.88 & 2.79 & 2.57 & 4.98 & 4.58 & 5.49 & 3.29 & 5.77 & 6.29 & 3.94 & 3.12 & 6.42 & 2.33 \\
\hline $\mathrm{Na}_{2} \mathrm{O}$ & 4.24 & 2.73 & 4.02 & 4.07 & 4.57 & 2.74 & 3.53 & 2.85 & 2.95 & 3.43 & 2.89 & 5.40 & 3.04 & 3.47 \\
\hline $\mathrm{K}_{2} \mathrm{O}$ & 3.34 & 4.64 & 2.29 & 4.43 & 3.41 & 2.67 & 3.28 & 3.18 & 2.39 & 2.45 & 3.13 & 0.96 & 1.81 & 3.71 \\
\hline $\mathrm{P}_{2} \mathrm{O}_{5}$ & 0.05 & 0.07 & 0.10 & 0.23 & 0.13 & 0.09 & 0.44 & 0.09 & 0.11 & 0.45 & 0.08 & 0.20 & 0.12 & 0.08 \\
\hline LOI & 1.44 & 2.41 & 2.06 & 1.66 & 3.32 & 1.65 & 1.21 & 2.07 & 1.10 & 2.16 & 2.08 & 1.88 & 2.09 & 1.50 \\
\hline Total & 99.97 & 99.50 & 99.28 & 99.90 & $\overline{100.45}$ & 99.71 & 99.56 & 99.74 & 98.73 & 99.37 & 99.70 & 99.82 & $\overline{100.71}$ & $\overline{100.43}$ \\
\hline \multicolumn{15}{|c|}{ Trace elements (ppm) } \\
\hline $\mathrm{Ba}$ & 461 & 491 & 417 & 708 & 552 & 410 & 597 & 404 & 306 & 821 & 414 & 189 & 295 & 364 \\
\hline $\mathrm{Rb}$ & 97 & 144 & 81 & 151 & 88 & 99 & 89 & 106 & 79 & 68 & 111 & 34 & 61 & 123 \\
\hline $\mathrm{Sr}$ & 37 & 76 & 302 & 329 & 204 & 241 & 555 & 223 & 261 & 595 & 218 & 145 & 324 & 163 \\
\hline $\mathrm{Y}$ & 29 & 13 & 7 & 21 & 23 & 10 & 29 & 10 & 12 & 26 & 18 & 34 & 11 & 11 \\
\hline $\mathrm{Zr}$ & 101 & 118 & 115 & 368 & 147 & 122 & 284 & 112 & 113 & 263 & 98 & 125 & 90 & 113 \\
\hline $\mathrm{Nb}$ & 8 & 5 & 4 & 15 & 9 & 6 & 12 & 4 & 2 & 13 & 5 & 8 & 3 & 5 \\
\hline Th & 13 & 14 & 15 & 22 & 3 & 14 & 15 & 14 & 6 & 15 & 7 & 5 & 9 & 22 \\
\hline $\mathrm{Pb}$ & 55 & 8 & 11 & 32 & 6 & 7 & 19 & 5 & 11 & 9 & 13 & 11 & 1 & 16 \\
\hline $\mathrm{Ga}$ & 14 & 12 & 15 & 18 & 13 & 14 & 22 & 13 & 16 & 20 & 15 & 14 & 18 & 16 \\
\hline $\mathrm{Zn}$ & 36 & 60 & 38 & 60 & 61 & 50 & 66 & 32 & 61 & 70 & 46 & 63 & 51 & 38 \\
\hline $\mathrm{Cu}$ & 201 & 0 & 10 & 124 & 14 & 8 & 35 & 28 & 33 & 76 & 30 & 15 & 28 & 7 \\
\hline $\mathrm{Ni}$ & 10 & 4 & 4 & 22 & 42 & 5 & 9 & 90 & 0 & 16 & 6 & $<3$ & 13 & 0 \\
\hline V & 33 & 46 & 72 & 84 & 122 & 73 & 159 & 82 & 107 & 178 & 90 & 95 & 129 & 51 \\
\hline $\mathrm{Cr}$ & 13 & 9 & 17 & 17 & 36 & 6 & 19 & 22 & 13 & 24 & $<4$ & $<4$ & 16 & 0 \\
\hline
\end{tabular}

\begin{tabular}{|c|c|c|c|c|c|c|c|c|c|c|c|c|c|}
\hline Pluton \# & 24 & 24 & 24 & 24 & 26 & 26 & 26 & 26 & 26 & 26 & 26 & 26 & 26 \\
\hline Sample & K99-520 & NB00-110 & NB00-111 & NB00-44 & K99-434 & K99-440 & K99-446A & K99-467 & NB00-109 & NB00-68 & NB00-75 & NB00-76 & NB00-91 \\
\hline Easting & 689950 & 689400 & 689550 & 694550 & 693050 & 690600 & 697900 & 702150 & 691700 & 693250 & 691050 & 691100 & 690500 \\
\hline Northing & 4997050 & 4998150 & 4998150 & 4999200 & 5001750 & 4999700 & 5004850 & 5008450 & 5000600 & 5000550 & 4999900 & 4999900 & 4999450 \\
\hline \multicolumn{14}{|c|}{ Major elements (wt. \%) } \\
\hline $\mathrm{SiO}_{2}$ & 68.50 & 66.22 & 65.86 & 74.30 & 68.01 & 75.56 & 58.79 & 67.64 & 70.10 & 64.70 & 67.17 & 75.99 & 63.52 \\
\hline $\mathrm{TiO}_{2}$ & 0.30 & 0.34 & 0.34 & 0.21 & 0.44 & 0.26 & 0.57 & 0.37 & 0.28 & 0.35 & 0.45 & 0.11 & 0.44 \\
\hline $\mathrm{Al}_{2} \mathrm{O}_{3}$ & 15.11 & 15.43 & 15.80 & 13.53 & 14.93 & 13.35 & 17.72 & 15.70 & 13.99 & 15.73 & 14.70 & 12.53 & 16.44 \\
\hline $\mathrm{Fe}_{2} \mathrm{O}_{3}{ }^{\mathrm{t}}$ & 3.26 & 3.27 & 3.58 & 1.53 & 4.08 & 1.38 & 6.83 & 3.52 & 2.51 & 4.24 & 4.18 & 0.97 & 5.12 \\
\hline $\mathrm{MnO}$ & 0.06 & 0.07 & 0.07 & 0.03 & 0.08 & 0.02 & 0.14 & 0.08 & 0.04 & 0.08 & 0.09 & 0.01 & 0.08 \\
\hline $\mathrm{MgO}$ & 1.20 & 1.45 & 1.69 & 0.63 & 1.81 & 0.63 & 3.11 & 1.57 & 1.24 & 1.90 & 1.87 & 0.36 & 2.33 \\
\hline $\mathrm{CaO}$ & 3.88 & 3.27 & 3.75 & 1.01 & 3.77 & 0.80 & 6.66 & 3.89 & 2.32 & 3.97 & 4.30 & 0.09 & 4.23 \\
\hline $\mathrm{Na}_{2} \mathrm{O}$ & 3.45 & 3.68 & 3.26 & 4.06 & 2.85 & 3.39 & 2.75 & 3.42 & 3.13 & 3.31 & 2.86 & 3.01 & 3.67 \\
\hline $\mathrm{K}_{2} \mathrm{O}$ & 2.67 & 3.36 & 3.19 & 2.92 & 2.64 & 3.21 & 2.20 & 2.29 & 2.85 & 2.94 & 2.72 & 5.28 & 2.14 \\
\hline $\mathrm{P}_{2} \mathrm{O}_{5}$ & 0.07 & 0.08 & 0.07 & 0.06 & 0.09 & 0.07 & 0.13 & 0.11 & 0.06 & 0.10 & 0.08 & 0.03 & 0.11 \\
\hline LOI & 1.09 & 1.93 & 1.59 & 0.68 & 1.31 & 1.61 & 1.18 & 1.52 & 2.23 & 1.99 & 2.10 & 0.75 & 1.89 \\
\hline Total & 99.58 & 99.10 & 99.20 & 98.95 & $\overline{100.01}$ & 100.28 & 100.08 & 100.11 & 98.75 & 99.31 & 100.52 & 999.12 & 99.97 \\
\hline
\end{tabular}

\begin{tabular}{|c|c|c|c|c|c|c|c|c|c|c|c|c|c|}
\hline \multicolumn{14}{|c|}{ Trace elements (ppm) } \\
\hline $\mathrm{Ba}$ & 212 & 487 & 402 & 584 & 793 & 235 & 178 & 500 & 560 & 389 & 441 & 728 & 446 \\
\hline $\mathrm{Rb}$ & 96 & 106 & 109 & 86 & 85 & 191 & 59 & 68 & 94 & 103 & 80 & 129 & 62 \\
\hline $\mathrm{Sr}$ & 233 & 195 & 192 & 96 & 217 & 118 & 295 & 256 & 205 & 214 & 226 & 65 & 233 \\
\hline $\mathrm{Y}$ & 7 & 15 & 16 & 19 & 10 & 9 & 20 & 6 & 13 & 17 & 24 & 13 & 18 \\
\hline $\mathrm{Zr}$ & 113 & 119 & 105 & 109 & 123 & 166 & 126 & 138 & 102 & 109 & 190 & 69 & 114 \\
\hline $\mathrm{Nb}$ & 6 & 5 & 5 & 6 & 4 & 14 & 6 & 4 & 3 & 4 & 6 & 5 & 5 \\
\hline Th & 16 & 11 & 11 & 7 & 15 & 56 & 7 & 8 & 9 & 9 & 15 & 27 & 9 \\
\hline $\mathrm{Pb}$ & 7 & 16 & 21 & 8 & 21 & 25 & 26 & 10 & 13 & 15 & 18 & 23 & 9 \\
\hline $\mathrm{Ga}$ & 18 & 13 & 16 & 12 & 15 & 17 & 18 & 16 & 12 & 15 & 14 & 9 & 15 \\
\hline $\mathrm{Zn}$ & 40 & 63 & 37 & 18 & 44 & 27 & 99 & 38 & 26 & 45 & 57 & 16 & 40 \\
\hline $\mathrm{Cu}$ & 0 & 11 & 28 & $<4$ & 39 & 0 & 38 & 3 & 112 & 30 & 28 & 9 & 24 \\
\hline $\mathrm{Ni}$ & 34 & 3 & 4 & 78 & 1 & 0 & 5 & 0 & $<3$ & 3 & 7 & $<3$ & 4 \\
\hline V & 55 & 66 & 70 & 32 & 82 & 11 & 142 & 75 & 52 & 72 & 91 & 22 & 97 \\
\hline $\mathrm{Cr}$ & 8 & $<4$ & $<4$ & $<4$ & 3 & 0 & 14 & 0 & $<4$ & $<4$ & 5 & $<4$ & $<4$ \\
\hline
\end{tabular}


Table 3. Hf, Ta, and rare-earth element data obtained by ICP-MS ${ }^{1}$

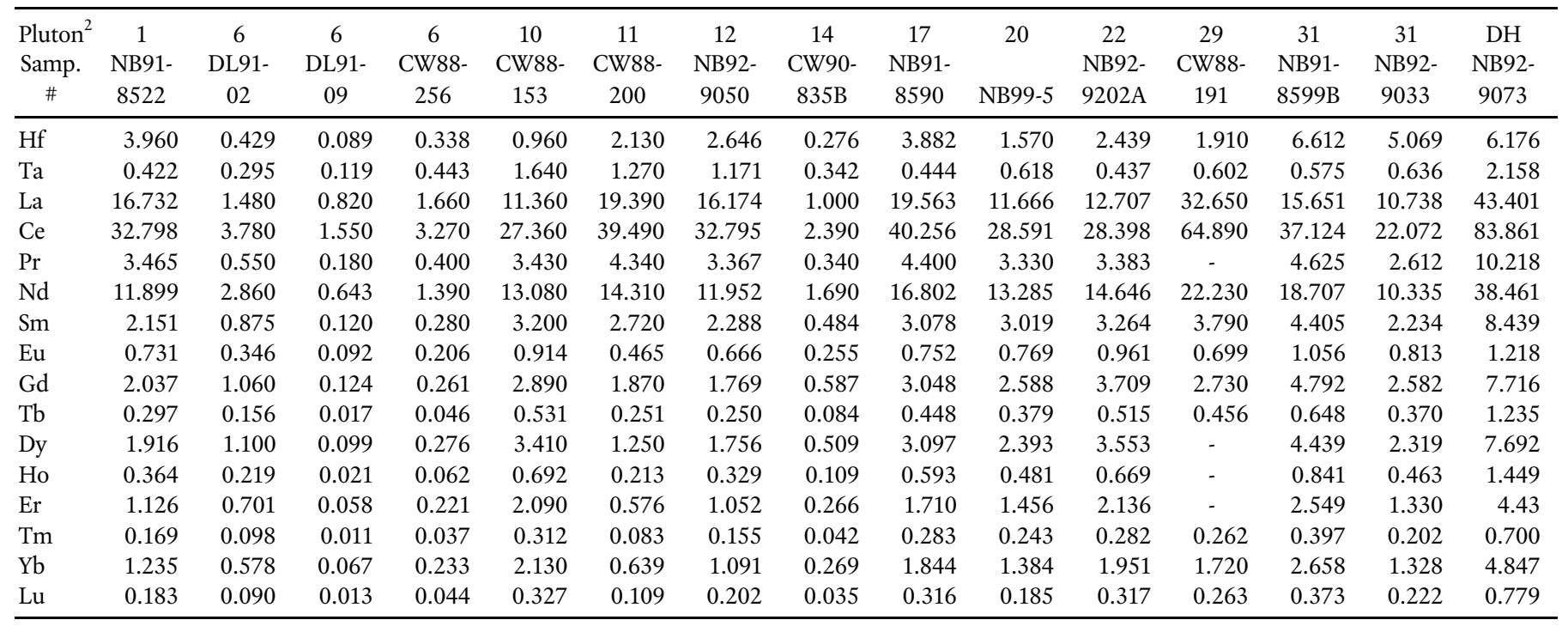

${ }^{1}$ Analyses at Memorial University by the $\mathrm{Na}_{2} \mathrm{O}_{2}$ sinter method (Longerich et al. 1990)

${ }^{2}$ Pluton numbers are from Table 1, except DH = Dipper Harbour volcanic unit. Sample locations are shown in White (1996) or listed in Table 2.

toward the northeast (White 1996). Granitic rocks exposed in the Cassidy Lake and Jeffrey Corner areas (Fig. 1) may be part of the Hammond River Granite. The Fairville and Chalet Lake plutons are characterized by large megacrysts of K-feldspar. The Fairville Granite is locally intruded by quartz diorite apparently related to the French Village Quartz Diorite, a relationship consistent with the U-Pb ages of these plutons (see below).

\section{Syenogranitic to monzogranitic plutons}

Most of the syenogranitic to monzogranitic plutons occur in the coastal part of the Brookville terrane, southwest of Saint John (Figs. 2,3). They are typically small, relatively homogeneous bodies, although the Musquash Harbour Pluton is larger and shows more compositional variation, including granodioritic and dioritic components. These plutons appear to lack mafic enclaves, and contain less than 5\% mafic minerals. Granophyric textures are common, suggesting that these plutons may be the high-level intrusive equivalents of the Dipper Harbour volcanic rocks, with which they show close spatial association (Figs. 2, 3). However, widespread Carboniferous thrusting (Nance 1987; White 1996) has obscured many of the original contact relationships in this area.

\section{GEOCHEMISTRY}

\section{Introduction}

A total of 163 chemical analyses for major and selected trace elements are available from the plutons of the Golden Grove Plutonic Suite. They include data from White (1996) and Eby and Currie (1996), as well as new data obtained in the present study (Table 2). Rare-earth element data are available for 48 samples,
14 from the present study (Table 3) and 32 from Eby and Currie (1996) and Currie (1996; written communication). The size of the data set precludes detailed discussion of chemical variations within individual plutons, and instead an overview of the chemical variations among plutons is emphasized. Because of the range in loss-on-ignition values in the samples, the major element oxide data have been recalculated to total $100 \%$ volatile-free before being plotted on the various diagrams.

\section{Gabbroic plutons}

The varied compositions of the Duck Lake and Indiantown gabbroic plutons are reflected in the chemical data. $\mathrm{SiO}_{2}$ content ranges from less than $40 \%$ in ultramafic samples to $48 \%$ in gabbroic and anorthositic samples (Fig. 4). Ranges in $\mathrm{Al}_{2} \mathrm{O}_{3}, \mathrm{CaO}$, and $\mathrm{Na}_{2} \mathrm{O}$ correlate with the varying abundance of plagioclase; anorthositic samples have more than $20 \% \mathrm{Al}_{2} \mathrm{O}_{3}, 14-18 \% \mathrm{CaO}$, and $1-2 \% \mathrm{Na}_{2} \mathrm{O}$ (Figs. 4b, e, f). Ultramafic (lowest $\mathrm{SiO}_{2}$ ) samples have higher $\mathrm{Fe}_{2} \mathrm{O}_{3}$ and $\mathrm{MgO}$ (Figs. 4c, d) and low $\mathrm{Al}_{2} \mathrm{O}_{3}, \mathrm{CaO}$, and $\mathrm{Na}_{2} \mathrm{O}$ (Figs. 4b, e, f). Most samples are low in $\mathrm{TiO}_{2}, \mathrm{~K}_{2} \mathrm{O}$, and $\mathrm{P}_{2} \mathrm{O}_{5}$ (Figs. 4a, g, h). The low $\mathrm{TiO}_{2}$ and $\mathrm{P}_{2} \mathrm{O}_{5}$ are in marked contrast to the Lower Coverdale gabbroic complex sampled in drill holes near Moncton (Fig. 1), in which $\mathrm{TiO}_{2}$ and $\mathrm{P}_{2} \mathrm{O}_{5}$ contents exceed $20 \%$ and $8 \%$, respectively, in some gabbroic samples (Barr et al. 2002d).

The gabbroic samples with highest $\mathrm{SiO}_{2}$ contents overlap with the most mafic (lowest $\mathrm{SiO}_{2}$ ) samples from the dioritic plutons. These overlapping samples have generally similar abundances of most major element oxides and in the cases of $\mathrm{Al}_{2} \mathrm{O}_{3}, \mathrm{MgO}, \mathrm{CaO}$, $\mathrm{Na}_{2} \mathrm{O}$, and $\mathrm{K}_{2} \mathrm{O}$ the gabbroic samples lie on reasonably linear trends with the dioritic samples (Figs. 4b, d, e, f, g), suggesting a genetic relationship. Trends are less continuous in the cases of $\mathrm{TiO}_{2}, \mathrm{Fe}_{2} \mathrm{O}_{3}{ }^{\mathrm{t}}$, and $\mathrm{P}_{2} \mathrm{O}_{5}$ (Figs. $4 \mathrm{a}, \mathrm{c}$, and $\mathrm{h}$ ), but those more erratic 

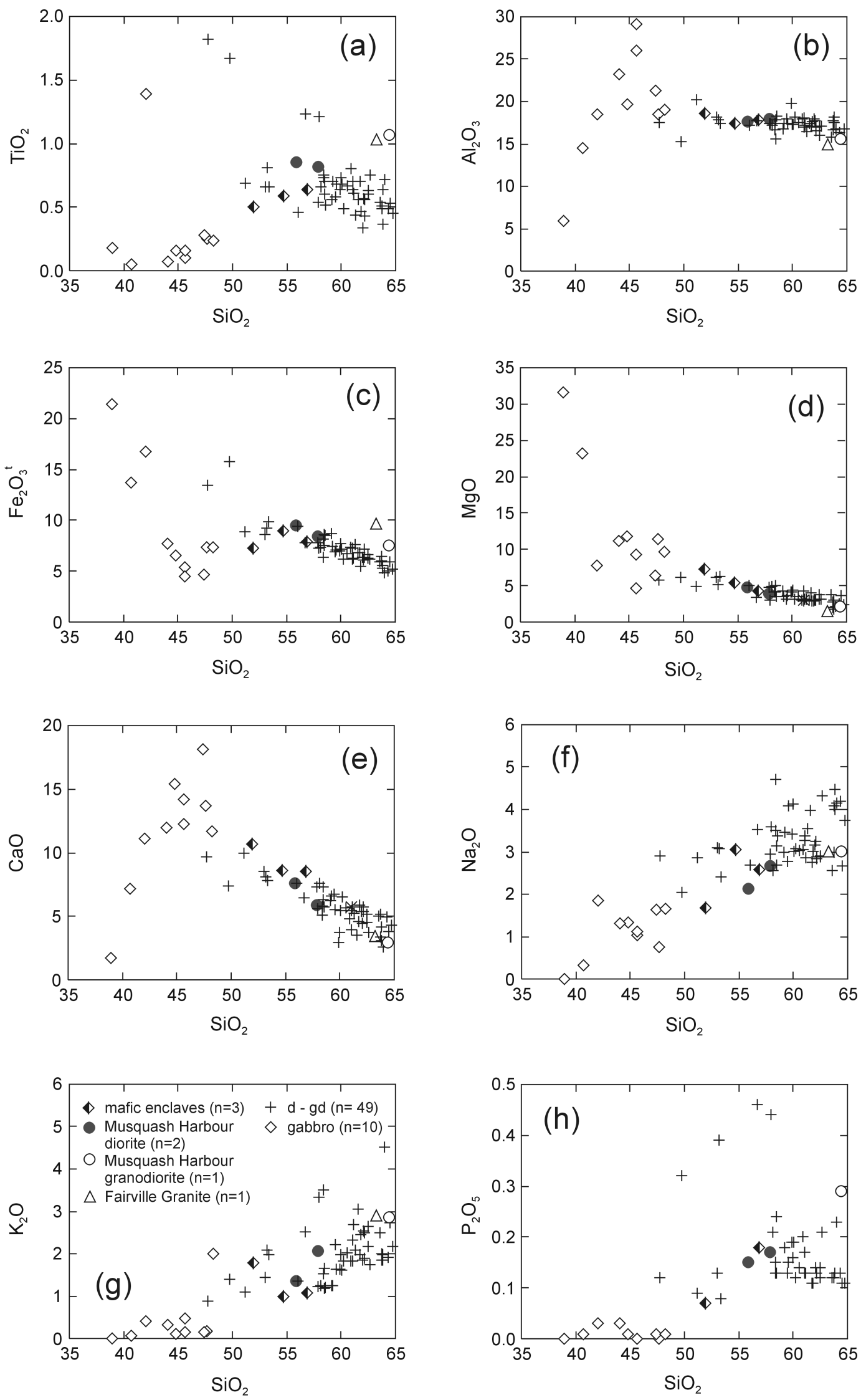

FIG. 4 Diagrams to illustrate chemical variations in gabbroic, dioritic, and granodioritic samples $\left(35-65 \% \mathrm{SiO}_{2}\right)$. All data are in weight $\%$. $\mathrm{Fe}_{2} \mathrm{O}_{3}{ }^{t}$ is total iron expressed as $\mathrm{Fe}_{2} \mathrm{O}_{3}$. Data are from Table 2 and sources described in text. The data shown for the Fairville Granite include 3 samples from the similar Chalet Lake Granite. Abbreviations: $d$, diorite; gd, granodiorite. 

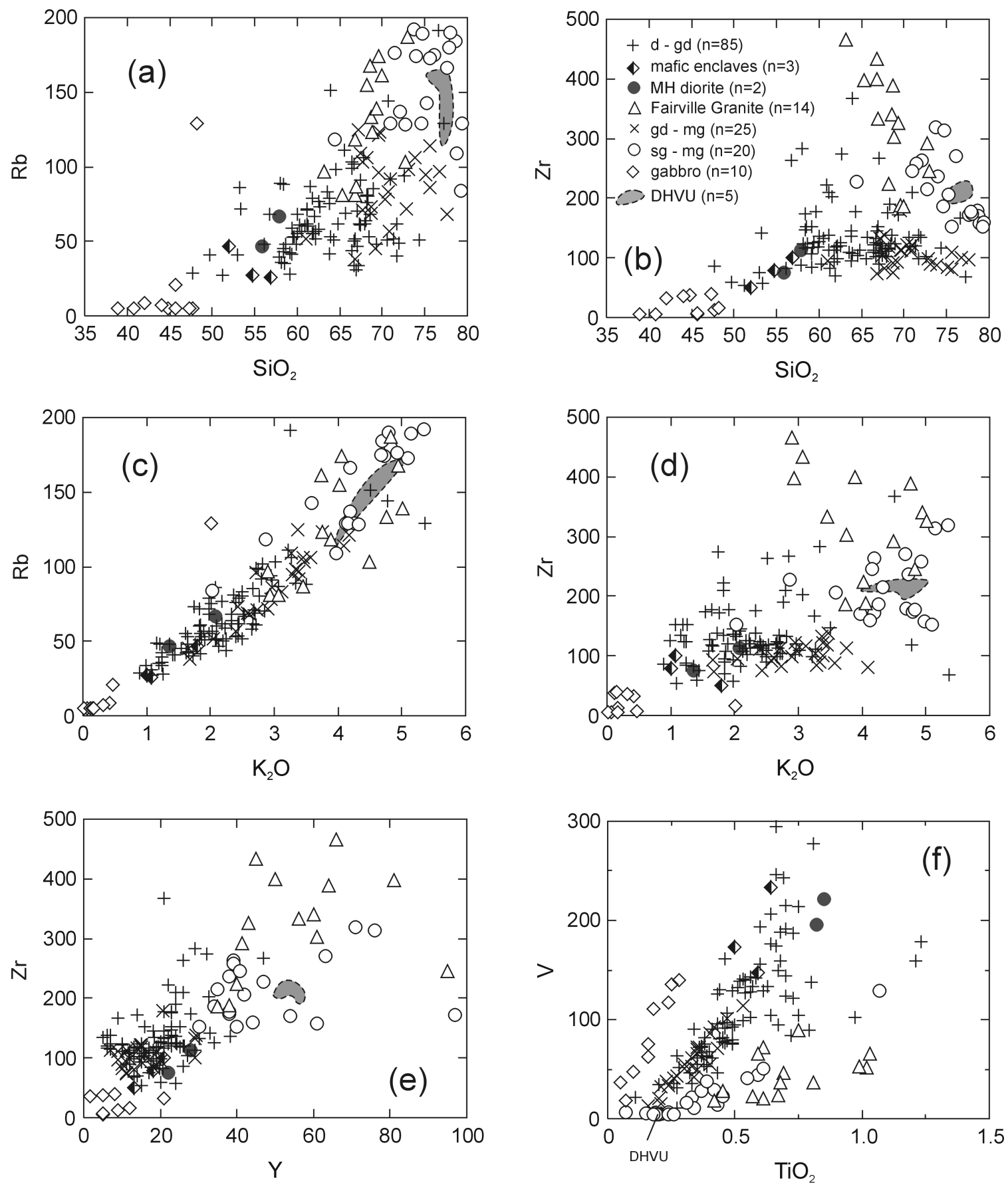

FIG. 5 Diagrams to illustrate trace element variations in all samples. Oxide data are in weight \%; elemental data are in ppm. Data are from Table 2 and sources described in text. Abbreviations: d, diorite; gd, granodiorite; $m g$, monzogranite; sg, syenogranite; MH, Musquash Harbour; DHVU, Dipper Harbour volcanic unit.

variations could result from fractionation of titaniferous magnetite, ilmenite, and apatite.

Trace elements such as $\mathrm{Rb}$ and $\mathrm{Zr}$ that are incompatible in mafic minerals and plagioclase are generally low in the gabbroic samples (Figs. 5a, b). Conversely, compatible elements show wide variation(e.g., V, 18 to $437 \mathrm{ppm}$; Cr, 36 to $2926 \mathrm{ppm}$, and Ni, 45 to $838 \mathrm{ppm}$ ) and positive correlation with $\mathrm{TiO}_{2}$ (Fig. 5f; one sample with $437 \mathrm{ppm} \mathrm{V}$ and $1.36 \% \mathrm{TiO}_{2}$ is off the scale of the figure) and $\mathrm{Fe}_{2} \mathrm{O}_{3}{ }^{\mathrm{t}}$ and $\mathrm{MgO}$ (not shown).

REE concentrations are low and, relative to chondritic values, show slight light REE enrichment (Fig. 6a). All four samples show slight to moderate enrichment in Eu, suggesting accumulation of plagioclase in the analyzed samples.

\section{Diorite to granodiorite}

The large range in chemical compositions in the dioritic to granodioritic plutons corresponds well with the range in modal mineralogy. $\mathrm{SiO}_{2}$ contents vary from less than $50 \%$ in dioritic samples to over $75 \%$ in the most granitic parts of some plutons, but 

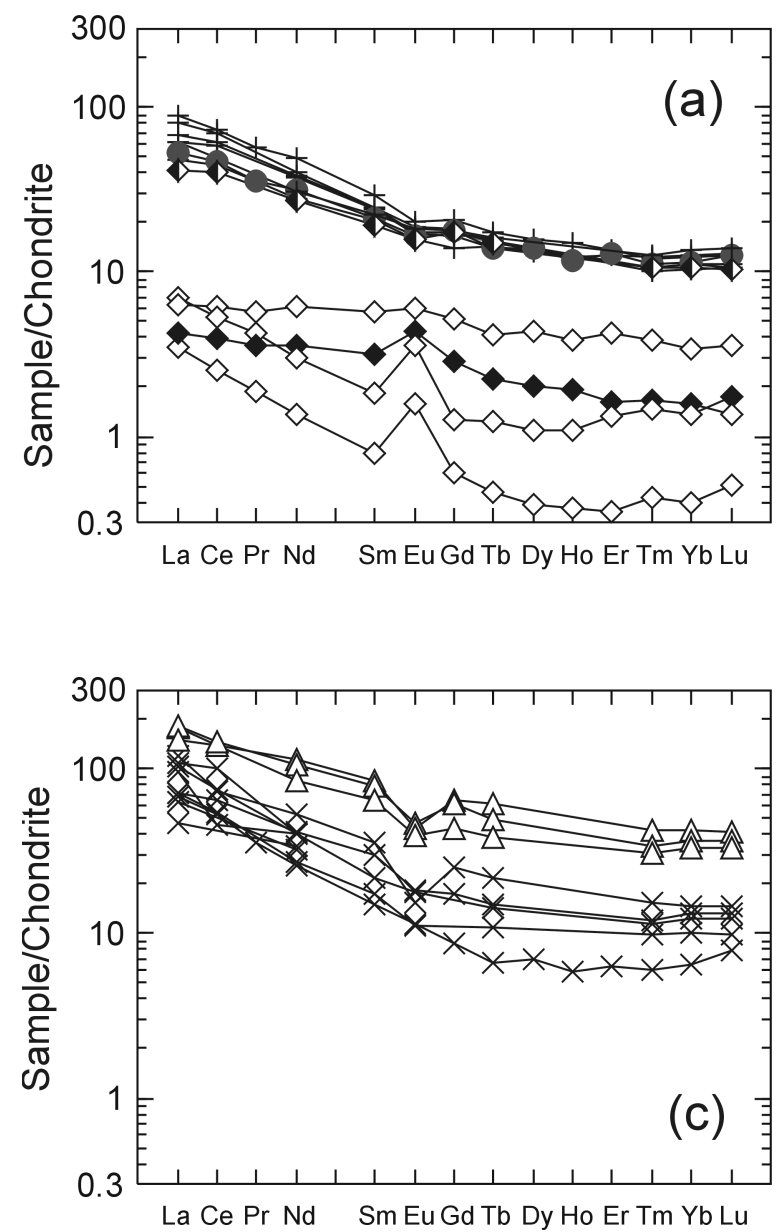
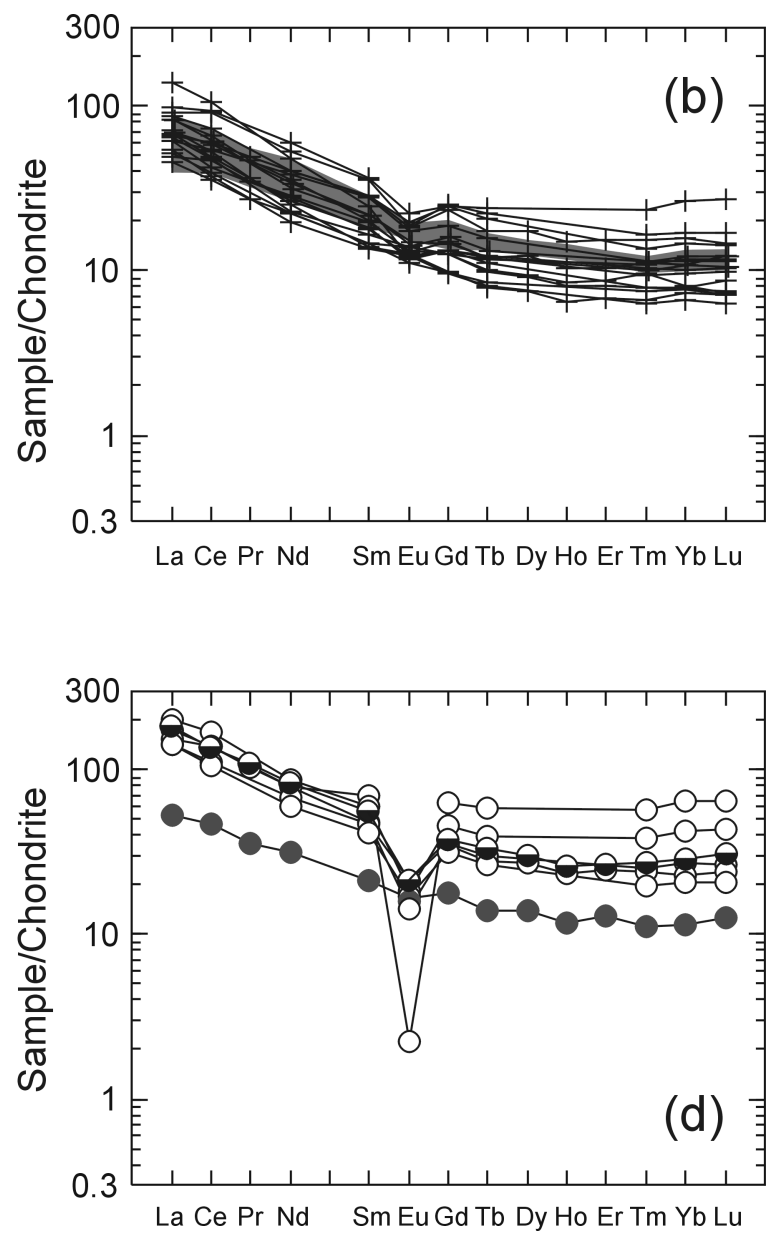

FIG. 6 Chondrite-normalized rare-earth element diagrams. (a) Samples from the Duck Lake pluton (open diamonds), Indiantown gabbro (filled diamonds), and 5 samples with less than $60 \% \mathrm{SiO}_{2}$ from other units (symbols as in Fig. 4). (b) Samples with more than $60 \% \mathrm{SiO}_{2}$ from the dioritic to granodioritic plutons. Shaded field includes the 5 samples with less than $60 \% \mathrm{SiO}^{2}$ from (a) for comparison. (c) Samples from the granodioritic and monzogranitic plutons; triangles are samples from the Fairville Granite. (d) Samples from the syenogranitic and monzogranitic plutons; the grey circle is a sample from the quartz dioritic part of the Musquash Harbour Pluton, and is also shown in (a). The half-shaded circle is sample NB92-9073 from the Dipper Harbour volcanic unit (Table 3). Chondrite-normalizing values are from Sun and McDonough (1989).

the majority of the samples are intermediate in composition, with between $60 \%$ and $70 \% \mathrm{SiO}_{2}$ (Fig. 7). Most major element oxides show a strong negative correlation with $\mathrm{SiO}_{2}$ (Figs. 7a, b, c, d, e, h), with the exceptions of $\mathrm{Na}_{2} \mathrm{O}$, which is relatively constant at 3-4\% (Fig. 7f), and $\mathrm{K}_{2} \mathrm{O}$, which shows a positive correlation with $\mathrm{SiO}_{2}$ (Fig. 7g). Trace elements such as $\mathrm{Ba}, \mathrm{Rb}$, and $\mathrm{Sr}$ that are compatible in feldspars, generally the most abundant minerals in these samples, show trends similar to the major oxides, as illustrated by $\mathrm{Rb}$ which shows strong correlation with $\mathrm{SiO}_{2}$ and $\mathrm{K}_{2} \mathrm{O}$ (Figs. $5 \mathrm{a}, \mathrm{c})$. The major and trace element trends are consistent with fractional crystallization of mafic minerals and feldspars as the major cause of chemical variation within this suite of plutons. In contrast, incompatible elements such as $\mathrm{Zr}$ show little co-variation with $\mathrm{SiO}_{2}$ or $\mathrm{K}_{2} \mathrm{O}$ (Figs. 5 b, d), but positive correlation with some other elements such as $\mathrm{Y}$ (Fig. 5e). Positive correlation between $\mathrm{V}$ and $\mathrm{TiO}_{2}$ follows a different trend than that in the Duck Lake and Indiantown gabbroic samples (Fig. 5f). This difference suggests that fractionation in the dioritic to granodioritic suite involved minerals with lower $\mathrm{V}$ relative to $\mathrm{Ti}$ than the gabbroic suite, or that the parental magmas for the gabbroic suite contained higher $\mathrm{V}$ relative to Ti.

Three samples from mafic enclaves in these plutons generally show chemical similarities to the dioritic samples with lowest $\mathrm{SiO}_{2}$ contents (Figs. 5,7). This similarity supports the possibility that the enclaves are cognate, and represent concentrations of minerals crystallized from the same magmas as their host rocks. This interpretation is further supported by REE data from one of the enclaves, which displays a chondrite-normalized pattern very similar to that of the dioritic rocks, but slightly less evolved (Fig. 6a). The REE patterns for the dioritic and granodioritic suite as a whole show light REE enrichment (La between 45 and 150 times chondritic values) and nearly flat heavy REE at 6.5 to 25 times chondritic values). The patterns are nearly parallel to one another and show slight to moderate negative Eu anomalies (Fig. $6 \mathrm{~b})$. These patterns are consistent with fractionation of plagioclase, amphibole, and biotite, as suggested by major and trace element variations. 

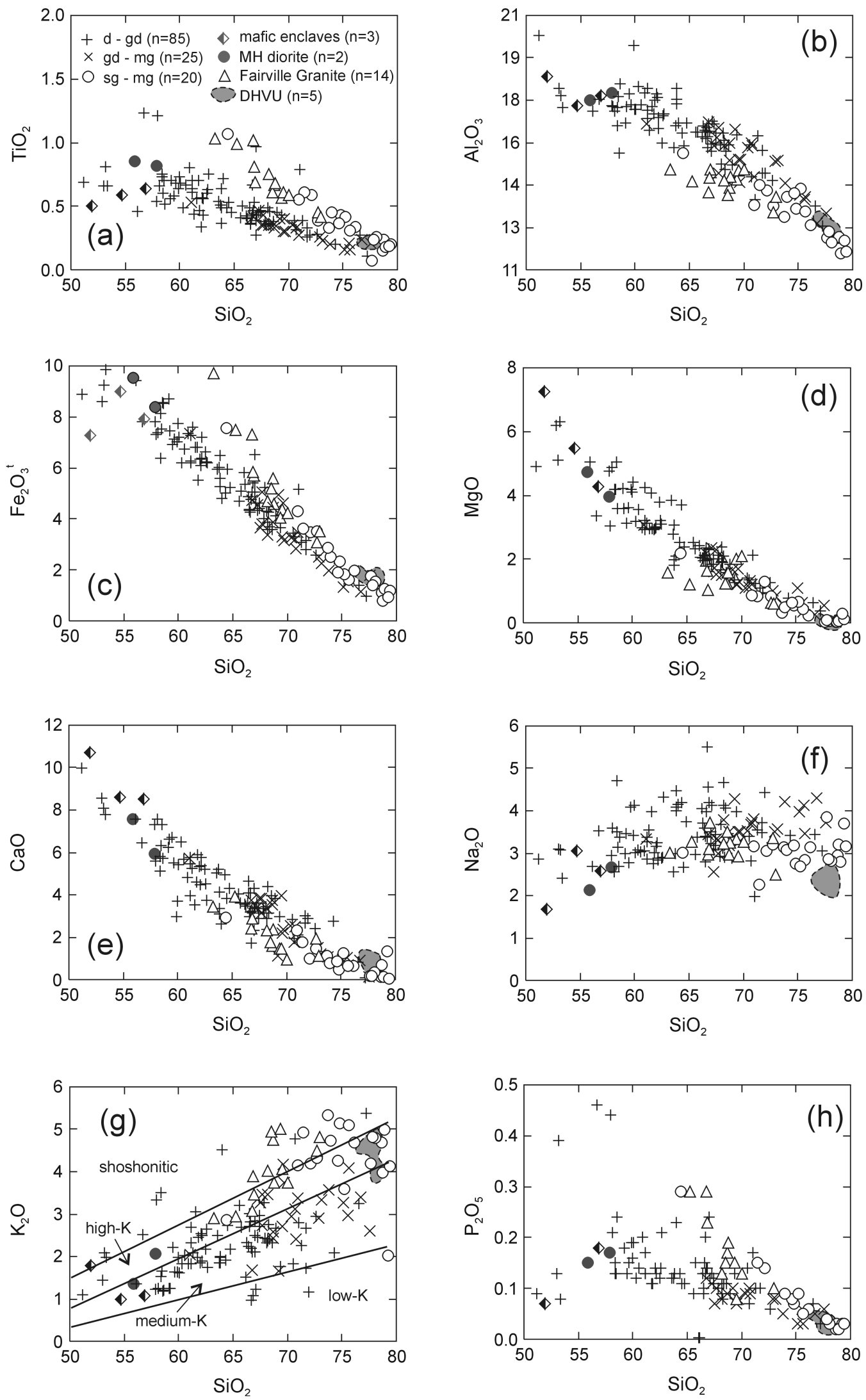

FIG. 7 Diagrams to illustrate chemical variations in dioritic to granitic samples $\left(50-80 \% \mathrm{SiO}_{2}\right)$. Note that the scale for $\mathrm{SiO}_{2}$ overlaps with and is the same as that in Fig. 4; samples with 50- 65\% $\mathrm{SiO}_{2}$ appear on both figures, but the vertical scales are different for $\mathrm{Al}_{2} \mathrm{O}_{3}, \mathrm{Fe}_{2} \mathrm{O}_{3}{ }^{t}$, $\mathrm{MgO}$, and $\mathrm{CaO}$. All data are in weight \% (after recalculation to total $100 \%$ volatile free). Fields in (g) are after Middlemost (1975). Symbols are as in Fig. 4. 


\section{Granodiorite and monzogranite}

Plutons in this group are dominated by granodiorite and monzogranite, consistent with their $\mathrm{SiO}_{2}$ contents which are mainly between $67 \%$ and $71 \%$, with rare more syenogranitic samples ranging up to $76 \% \mathrm{SiO}_{2}$ (Fig. 7). One sample from the Hanson Stream Granodiorite analyzed by Eby and Currie (1996) contains about $60 \% \mathrm{SiO}_{2}$ and may be from a mafic enclave. The samples show compositional overlap with data from the more abundant dioritic to granodioritic plutons and together the two groups of plutons form strong trends, with the exception of the samples from the Fairville and Chalet Lake plutons. The latter samples show trends of higher $\mathrm{TiO}_{2}, \mathrm{Fe}_{2} \mathrm{O}_{3}{ }^{\mathrm{t}}$, and $\mathrm{K}_{2} \mathrm{O}$ and lower $\mathrm{Al}_{2} \mathrm{O}_{3}, \mathrm{MgO}$, and $\mathrm{CaO}$ compared to the other plutons (Fig. 7). Trace elements show similar differences; for example, many of the analyzed samples from the Fairville and Chalet Lake plutons have higher Rb, Zr, and Y (Figs. 5a, b, d, e) and lower V (Fig. 5f). Total REE concentrations are higher, especially the heavy REE (Fig. 6c). In contrast, the other granodioritic and monzogranitic plutons have REE patterns similar to those of the dioritic to granodioritic samples.

\section{Syenogranite and monzogranite}

Analyzed samples from the syenogranitic to monzogranitic plutons have more than $70 \% \mathrm{SiO}_{2}$, with the exception of 2 samples from the more mafic parts of the composite Musquash Harbour Pluton (Fig. 7). They generally have higher $\mathrm{SiO}_{2}$ contents than samples from the granodioritic and monzogranitic plutons, although there is considerable overlap. However, on many of the major element variation diagrams, the syenogranitic samples form linear trends with samples from the Fairville and Chalet Lake plutons, trends that involve higher $\mathrm{TiO}_{2}, \mathrm{Fe}_{2} \mathrm{O}_{3}{ }^{\mathrm{t}}$, and $\mathrm{K}_{2} \mathrm{O}$ and lower $\mathrm{Al}_{2} \mathrm{O}_{3}, \mathrm{MgO}$, and $\mathrm{CaO}$ compared to the trends of the other plutons. Trace elements show similar variations; the syenogranitic and monzogranitic suite of samples has higher $\mathrm{Rb}, \mathrm{Zr}$, and $\mathrm{Y}$ (Figs. $5 \mathrm{a}, \mathrm{b}, \mathrm{e}$ ) and lower $\mathrm{V}$ (Fig. 5f). They tend to form scattered trends with the samples from the Fairville and Chalet Lake plutons that differ from those in the remaining samples, such as a negative correlation between $\mathrm{Zr}$ and $\mathrm{SiO}_{2}$ (Fig. $5 \mathrm{~b}$ ). The REE values are higher and like those in the Fairville Granite, although they display wider variation in heavy REE and more pronounced negative Eu anomalies than the Fairville Granite samples (Fig. 6d). Such differences suggest that these plutons may be related by fractionation of Kfeldspar and zircon.

In contrast to the differences displayed by the syenogranitic to granodioritic samples from the Musquash Harbour Pluton, two quartz diorite samples and a granodiorite sample from that pluton are chemically like dioritic samples from the dioritic to granodioritic suite, and generally plot within the trends defined by those samples (Figs. 5,7). The similarity is also shown by the REE data from one of these samples, which is identical to the REE pattern of the other dioritic samples (Fig. 6a). These data suggest that the dioritic parts of the Musquash Harbour Pluton may not be cogenetic with its more voluminous granitic parts, and may instead be related to the dioritic - granodioritic plutons of the Brookville terrane.

A field for 5 analyzed samples from the Dipper Harbour volcanic unit is shown on the various chemical plots for comparison with the granitoid rocks. The samples show limited chemical variation, and are similar to samples from the syenogranitic plutons, with about $77-78 \% \mathrm{SiO}_{2}$ (Fig. 7). Like those plutons they show elevated contents of $\mathrm{Rb}, \mathrm{Zr}$, and $\mathrm{Y}$, and low $\mathrm{V}$ and $\mathrm{TiO}_{2}$ (Fig. 5), and similarly have within-plate and A-type characteristics (Fig. 8). The REE pattern of one sample (NB92-9073; Table 3) is similar to those of the syenogranitic samples (Fig. 6d). These chemical similarities support a comagmatic relationship between the syenogranitic plutons and the volcanic rocks, also suggested by their spatial association and $\mathrm{U}-\mathrm{Pb}$ ages, as noted above.

\section{Chemical affinity and tectonic setting}

Most of the analyzed samples plot on a clear calc-alkaline trend on an AFM diagram (Fig. 8a), although some samples from the Fairville, Chalet Lake, and syenogranitic plutons plot away from the trend because of their higher Fe contents, and most gabbroic samples plot toward the $\mathrm{MgO}$ corner. Most of the dioritic to granodioritic samples, as well as the granodioritic and monzogranite samples, plot in the volcanic arc field on $\mathrm{Zr}-\mathrm{TiO}_{2}$ and $\mathrm{Rb}-\mathrm{Y}+\mathrm{Nb}$ tectonic setting discrimination diagrams (Figs. 8b, c). However, on both of these diagrams, the syenogranitic and monzogranitic samples, and those from the Dipper Harbour volcanic unit and the Fairville and Chalet Lake plutons, are offset toward the withinplate fields. Samples for which $\mathrm{Th}, \mathrm{Yb}$, and Ta data are available plot mainly in the active continental margin field (Fig. 8d). Most samples have "I-type" affinities, although the syenogranitic and monzogranitic samples, as well as those from the Dipper Harbour volcanic unit and Fairville and Chalet Lake plutons, mainly plot in the A-type fields (Figs. 8e, f), consistent with their "within-plate" tendencies.

\section{GEOCHRONOLOGY}

\section{Introduction}

The five U-Pb dates reported here were done by three of the authors in different laboratories, although the methodology was similar. The Fairville Granite and Ludgate Lake Granodiorite samples were dated by C. White in the laboratory of G. Dunning at Memorial University of Newfoundland, by methods described in White (1996). The Lutes Mountain Diorite and McCarthy Point Granodiorite were dated by B. Miller at the University of North Carolina, Chapel Hill, using methods similar to those described by Ratajeski et al. (2001). The sample from the Duck Lake Pluton was dated by M. Hamilton at the Geological Survey of Canada, Ottawa, using methods described by Barr et al. (2000). The analytical data for all five samples are presented in Table 4, together with UTM co-ordinates of sample locations. 

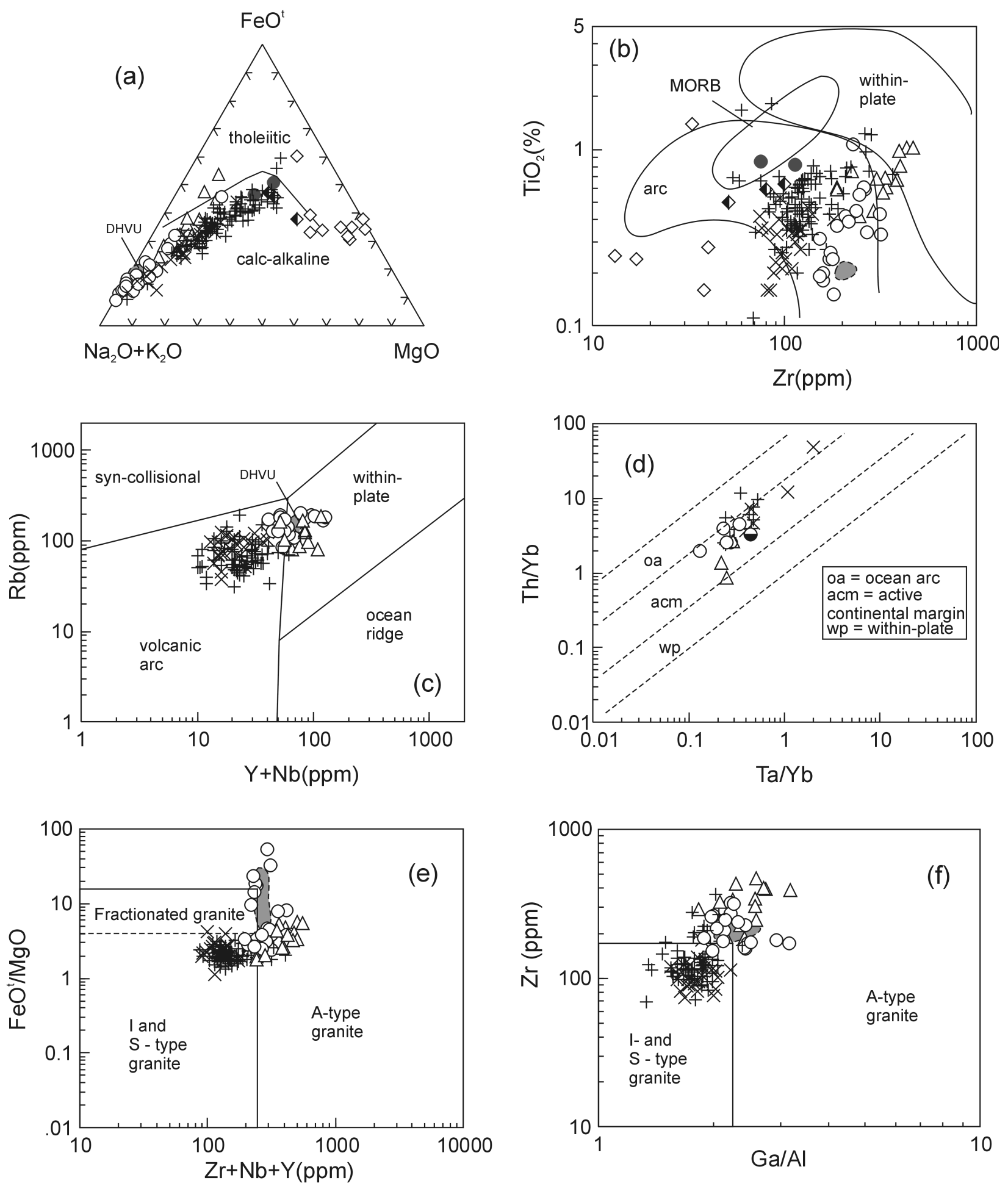

FIG. 8 Diagrams to indicate chemical affinity and/or tectonic setting. Fields are from (a) Irvine and Baragar (1971), (b) Pearce (1982), (c) Pearce et al. (1984), (d) Gorton and Schandl (2000), and (e,f) Whalen et al. (1987). Only intermediate and felsic samples $\left(>60 \% \mathrm{SiO}_{2}\right)$ are plotted on (c) to (f). Symbols are as in Figs. 5 and 6. 


\section{Duck Lake Gabbro}

A pegmatoid area within texturally and compositionally varied gabbro near the northwestern margin of the Duck Lake Pluton was sampled for dating. Dated sample DL97-1 was mostly coarse-grained plagioclase-rich gabbro, locally with abundant hornblende and minor quartz. Zircon grains recovered from the sample were mostly colourless to very pale brown and subhedral to anhedral in shape, the latter suggesting relatively late magmatic growth. Individual grains ranged from approximately 75-150 $\mu \mathrm{m}$ in maximum dimension. All grains were relatively clear and inclusion-free. However, many zircon grains showed minor, thin overgrowths of probable metamorphic origin. All grains were therefore given extensive air abrasion treatment (up to ca. 35 hours) to remove all optical signs of rims, and the best quality grains were subsequently re-picked from these populations, for chemistry.

Analysis of four fractions, each comprising between 52-70 grains, yielded results that are tightly clustered, lying on or immediately below concordia, and have ${ }^{207} \mathrm{~Pb} /{ }^{206} \mathrm{~Pb}$ ages which range narrowly between 538.9 and $540.4 \mathrm{Ma}$ (Table 4, Fig. 9a). The minor discordance displayed by the data $(0.3-0.9 \%)$ can be modelled by recent (modern-day) Pb-loss. The zircon data collectively define a weighted mean ${ }^{207} \mathrm{~Pb} /{ }^{206} \mathrm{~Pb}$ age of $539.6 \pm 1.2 \mathrm{Ma}$, which we interpret to represent the igneous crystallization age of the Duck Lake Gabbro.

\section{Fairville Granite}

Sample NB92-9012 was collected from the Fairville Granite in a road cut south of Green Head Island. It consisted of coarsegrained inequigranular biotite monzogranite, typical of the pluton. It yielded a zircon population composed of colourless to very pale yellow euhedral dipyramidal prisms, with length/ breadth ratio of about 3.3. The grains showed good to excellent clarity, with clear tube- or bubble-like inclusions and no visible evidence of inherited cores. Two abraded zircon fractions (Z1, Z3) were hand picked, avoiding any grains with inclusions, and a third abraded fraction (Z2) contained minor inclusions. Analyses of Z1 and $Z 3$ are slightly discordant $(<3.3 \%)$ with ${ }^{207} \mathrm{~Pb} /{ }^{206} \mathrm{~Pb}$ ages of ca. $570 \mathrm{Ma}$ and $560 \mathrm{Ma}$, respectively (Table 4). Analysis of fraction Z2 is $11.4 \%$ discordant and has a significantly older ${ }^{207} \mathrm{~Pb} /{ }^{206} \mathrm{~Pb}$ age of ca. $631 \mathrm{Ma}$ (Table 4). The three fractions define a simple discordia line with lower and upper intercept ages of $548 \pm 2 \mathrm{Ma}$ and 1997 $+280 /-215 \mathrm{Ma}$, respectively (Fig. 9b). The lower intercept age is the best estimate of the minimum age of emplacement of the Fairville Granite. The upper intercept indicates the presence of a significant component of inherited zircon with an average Early Proterozoic age.

\section{Lutes Mountain Diorite}

Dated sample NB00-11 was collected from a large quarry at the summit of Lutes Mountain north of Moncton. It was a mediumgrained diorite that consisted mainly of plagioclase and blue-green amphibole, with minor interstitial quartz and accessory titanite, zircon, apatite, and opaque minerals. Five fractions of zircon were analyzed from the sample. Each of three fractions consisted of three or four grains of medium-sized $(100 \times 40 \mu \mathrm{m})$ prismatic zircons. The other two fractions $(35$ and $110 \mu \mathrm{m})$ consisted of multi-faceted equant grains (Table 4). One fraction is concordant at $542 \mathrm{Ma}$ and two others are nearly concordant. Two additional analyses are discordant along a recent $\mathrm{Pb}$-loss line. One fraction has large $\mathrm{U}-\mathrm{Pb}$ errors because of an imprecise uranium analysis. All five analyses fit on a discordia line with an upper intercept of $542.2+1.8 /-1.4 \mathrm{Ma}$ and a lower intercept suggestive of recent $\mathrm{Pb}$-loss. We interpret the upper intercept age to be the time of crystallization of the Lutes Mountain Diorite.

\section{Ludgate Lake Granodiorite}

Sample NB91-9010 was collected from the Ludgate Lake Granodiorite at a roadcut on highway 1, about $300 \mathrm{~m}$ west of Ludgate Lake. It was a medium-grained inequigranular biotitehornblende granodiorite, and contained two morphologically distinct zircon populations. The most abundant grains $(>60 \%)$ are colourless, euhedral, needle-shaped, dipyramidal simple prisms, with an average length to breadth ratio of about 6 . They exhibited excellent clarity with minor clear tubes and bubbles as inclusions, and no visible cores. The other $40 \%$ of the zircon grains are stubby to slightly elongate, euhedral, clear, colourless multifaceted dipyramids with an average length to breadth ratio of 2. They have clear tubes and bubbles as inclusions, and no visible cores. Three fractions were analyzed, one from the needle-shaped prisms (Z1) and two from the stubby population (Z2 and Z3). The analyses are clustered and slightly discordant $(<2 \%)$ with ${ }^{207} \mathrm{~Pb} /$ ${ }^{206} \mathrm{~Pb}$ ages of ca. 548 to $544 \mathrm{Ma}$.

The sample also contained titanite, light amber to dark brown, clear to slightly cloudy with an anhedral to subhedral shape, and no visible inclusions or cores. Two fractions (T1 and T2) were analyzed, of which T1 was more abraded than T2. Both fractions are slightly discordant, although $\mathrm{T} 1$ yields a ${ }^{207} \mathrm{~Pb} /{ }^{206} \mathrm{~Pb}$ age of ca. 545 $\mathrm{Ma}$. The zircon and titanite fractions together define a discordia line with an upper intercept of $546 \pm 2 \mathrm{Ma}$, which is interpreted to be the crystallization age of the Ludgate Lake Granodiorite. The lower intercept of ca. $30 \mathrm{Ma}$ is uncertain due to the length of projection, but probably reflects recent $\mathrm{Pb}$ loss. The agreement of the titanite age and the upper intercept age suggests rapid cooling, at least through the closure temperature of titanite, as also confirmed by ${ }^{40} \mathrm{Ar} /{ }^{39} \mathrm{Ar}$ ages of hornblende (see below).

\section{McCarthy Point Granodiorite}

Dated sample NB99-5 was collected at the shoreline on the western side of McCarthy Point in Pocologan Harbour. It was a medium- to coarse-grained biotite-hornblende granodiorite typical of the pluton, and contained zircon grains of several different morphologies. In general, smaller grains were clear and free of inclusions, whereas larger grains tended to be slightly metamict. Seven zircon fractions were analyzed, of which five consisted of one or two grains and the remaining two were multi-grain fractions. None of the fractions shows evidence of inheritance. 


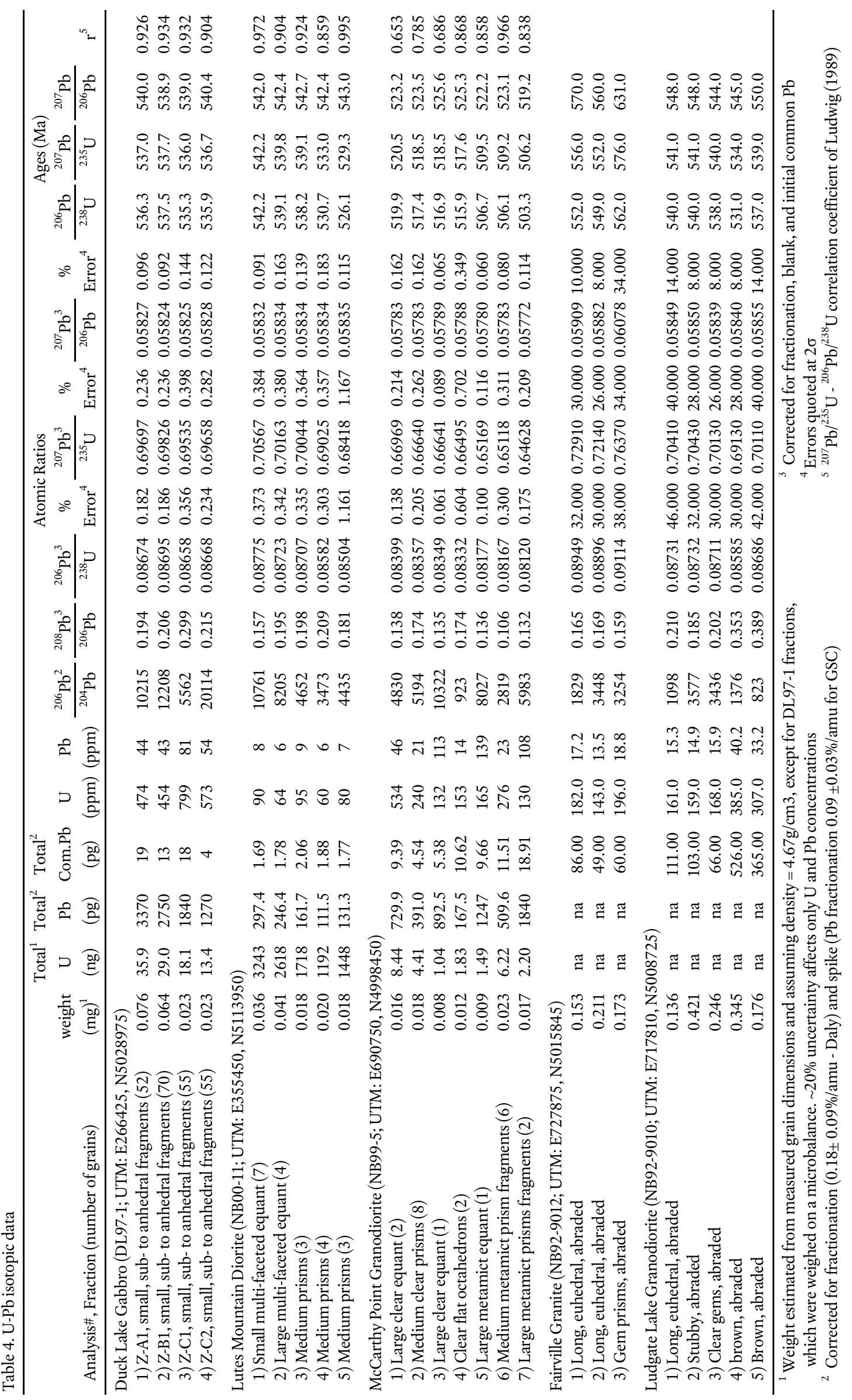



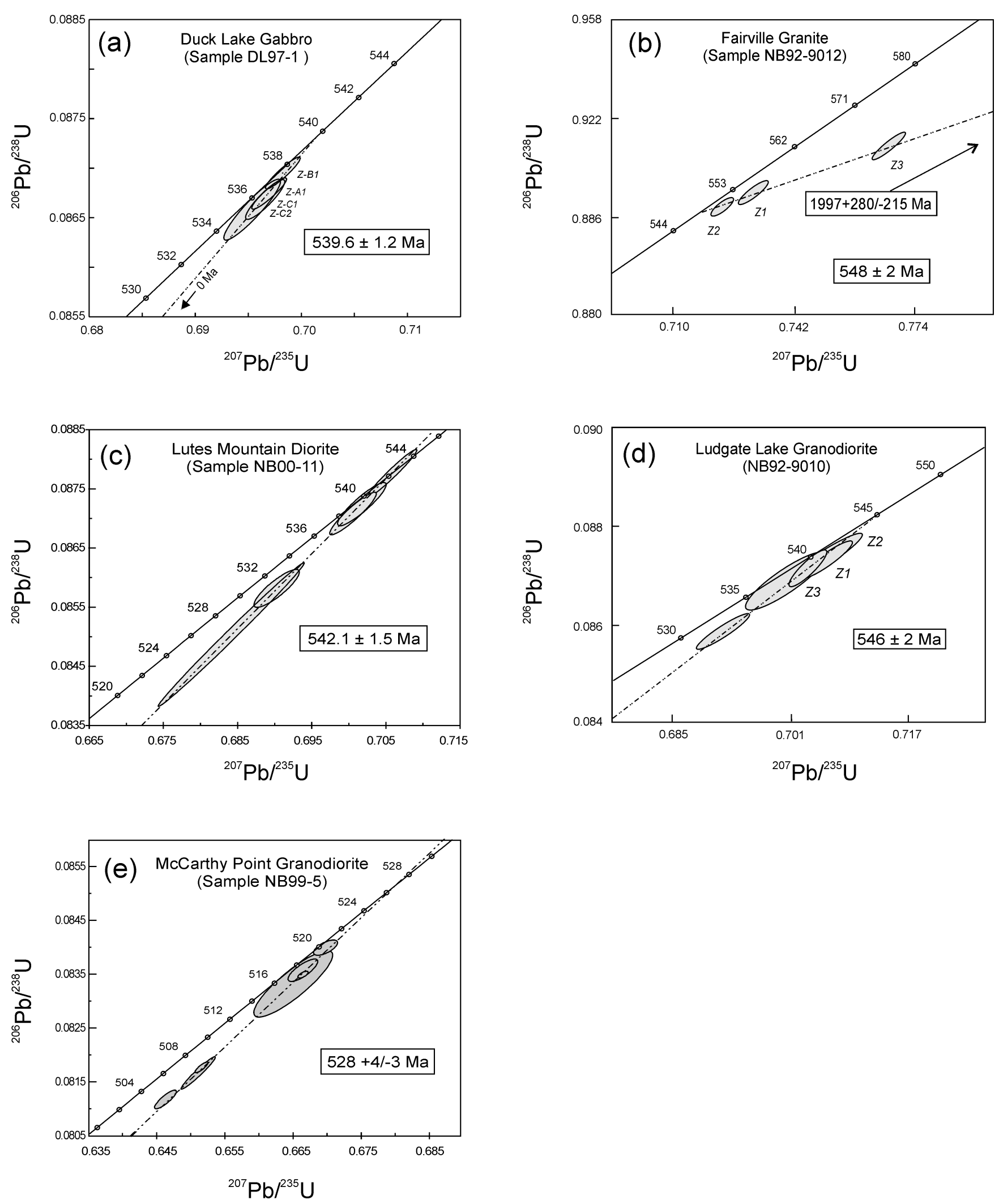

FIG. 9 Concordia diagrams for samples from (a)Duck Lake Pluton, (b) Fairville Granite, (c) Lutes Mountain Diorite, (d) Ludgate Lake Granodiorite, and (e) McCarthy Point Granodiorite. Data are given in Table 4. 
The metamict grains are more discordant than the clear grains, although both types were highly abraded. The seven fractions form a discordant trend with an upper intercept of $528+4 /-3 \mathrm{Ma}$, which we interpret to represent the time of crystallization of the pluton.

\section{Age Data Compilation}

Including the data presented here and previously published dates, ten U-Pb (zircon) ages have been obtained from the Golden Grove Plutonic Suite, although the age from the Musquash Harbour syenogranite has a large error associated with it (Table 1; Fig. 10). The spread of ages between about $550 \mathrm{Ma}$ and $525 \mathrm{Ma}$ is real, in that the error ranges of the older and younger dates do not overlap (Fig. 10). No strong pattern of age in comparison to pluton composition or location is apparent. For example, although the two youngest ages are both from plutons in the southwestern part of the terrane, one of the oldest plutons (Harvey Hill) is in the same area.

Additional constraints on the minimum ages of pluton emplacement are provided by ${ }^{40} \mathrm{Ar} /{ }^{39} \mathrm{Ar}$ ages from hornblende in the plutons, in some cases by more than one age determination from the same pluton. Taking errors into account, the ${ }^{40} \mathrm{Ar} /{ }^{39} \mathrm{Ar}$ cooling ages show a range very similar to that of the U-Pb crystallization ages, from close to $550 \mathrm{Ma}$ to about $520 \mathrm{Ma}$. They indicate that the plutons cooled rapidly through at least the argon retention temperature in hornblende $\left(\mathrm{ca} .525^{\circ} \mathrm{C}\right.$; McDougall and Harrison 1988). Hornblende and phlogopite ages from the host rocks of the pluton (both the Green Head Group and the Brookville Gneiss) show similar ages (Fig. 10), consistent with the interpretation that they record pervasive contact metamorphism. The similarity in zircon and titanite $\mathrm{U}-\mathrm{Pb}$ ages and ${ }^{40} \mathrm{Ar} /{ }^{39} \mathrm{Ar}$ cooling ages suggests that the plutons were emplaced are relatively shallow depth and cooled rapidly. Muscovite ${ }^{40} \mathrm{Ar} /{ }^{39} \mathrm{Ar}$ ages are somewhat younger ca. $520 \mathrm{Ma}$ to $505 \mathrm{Ma}$, perhaps reflecting a decrease in the rate of cooling through the argon retention temperature for muscovite (ca. $325^{\circ} \mathrm{C}$; Snee et al. 1988). Alternatively, the younger ages may reflect a subsequent reheating event.

The similarity in age at ca. $550 \mathrm{Ma}$ between the Dipper Harbour volcanic unit and the syenogranitic plutons is consistent with a comagmatic relationship between them. The relationship is also suggested by the chemical similarities discussed above.

\section{DISCUSSION}

The age data show that the Fairville Pluton is older than the other dated plutons. Like the Fairville and similar Chalet Lake plutons, the syenogranitic to monzogranitic plutons are different from the other plutons, and are also probably older, although the age of $544 \pm 4 \mathrm{Ma}$ from the Harvey Hill pluton (Currie and McNicoll 1999) suggests that the "A-type" magmatism overlapped with the more voluminous dioritic to monzogranitic plutons.

Eby and Currie (1996) postulated that plutons emplaced in the early part of the magmatic event in the Brookville terrane have characteristics typical of continental margin magmatism, with the exception of the Fairville pluton. They postulated that the igneous pulse terminated with A-type magmatism represented by the Harvey Hill and Prince of Wales plutons. However, this scenario is no longer viable, as it is clear that the Harvey Hill and Fairville plutons are the same age, as are probably the Musquash Harbour, Jarvies Lake, Cranberry Head, and Fishing Cove plutons, and Dipper Harbour volcanic unit. Hence it appears that magmatism in the Brookville terrane began with A-type characteristics (presumably continental extension) but at virtually the same time, continental margin-type subduction began, and continued to about $527 \mathrm{Ma}$ to generate the voluminous gabbroic to monzogranitic (dominantly granodioritic) plutons that comprise most of the Golden Grove Plutonic Suite.

Although Eby and Currie (1996) and Currie and McNicoll (1999) suggested that the plutons of the Brookville terrane are related to those in the adjacent Caledonia terrane and the New River terrane to the north, Barr and White (1996) argued that they are younger and part of a separate and unrelated tectonic regime. One of the strongest arguments in support of the latter interpretation is the fact that non-orogenic Cambrian sedimentary rocks were being deposited in the Caledonia and New River terranes while most of the Golden Grove Plutonic Suite was being formed in an active subduction zone; that argument is further supported by the new ages presented here. Detailed comparisons among the plutons of the Golden Grove Plutonic Suite and those of the adjacent Caledonia and New River terranes will be the topic of a subsequent paper.

\section{ACKNOWLEDGEMENTS}

The initial work on plutons of the Brookville terrane formed part of a $\mathrm{PhD}$ thesis by C.E. White at Dalhousie University. He thanks Becky Jamieson, Nick Culshaw, and Peter Reynolds for their help with the project, and Greg Dunning for his help with U-Pb analyses and interpretations for the Fairville and Ludgate Lake plutons, which were done in the geochronology lab at the Department of Earth Sciences, Memorial University of Newfoundland. Tassos Grammatikopoulos and Kevin Deveau made important contributions to our understanding of some of the plutons in the Brookville terrane. We thank Damian Nance for his stimulating discussions over the years about the complexity of the Brookville terrane. We are also grateful to him and the other journal reviewer, David Gibson, as well as editor Rob Fensome and publications manager David McMullin, for their helpful comments for improving the manuscript. Field studies were funded in part by the 1984-89 Canada-New Brunswick Mineral Development Agreement, the 1990-95 Canada-New Brunswick Cooperation Agreement on Mineral Development, collaborative research agreements with the N.B. Department of Natural Resources and energy, and Natural Sciences and Engineering Research Council of Canada grants to S.M. Barr. 


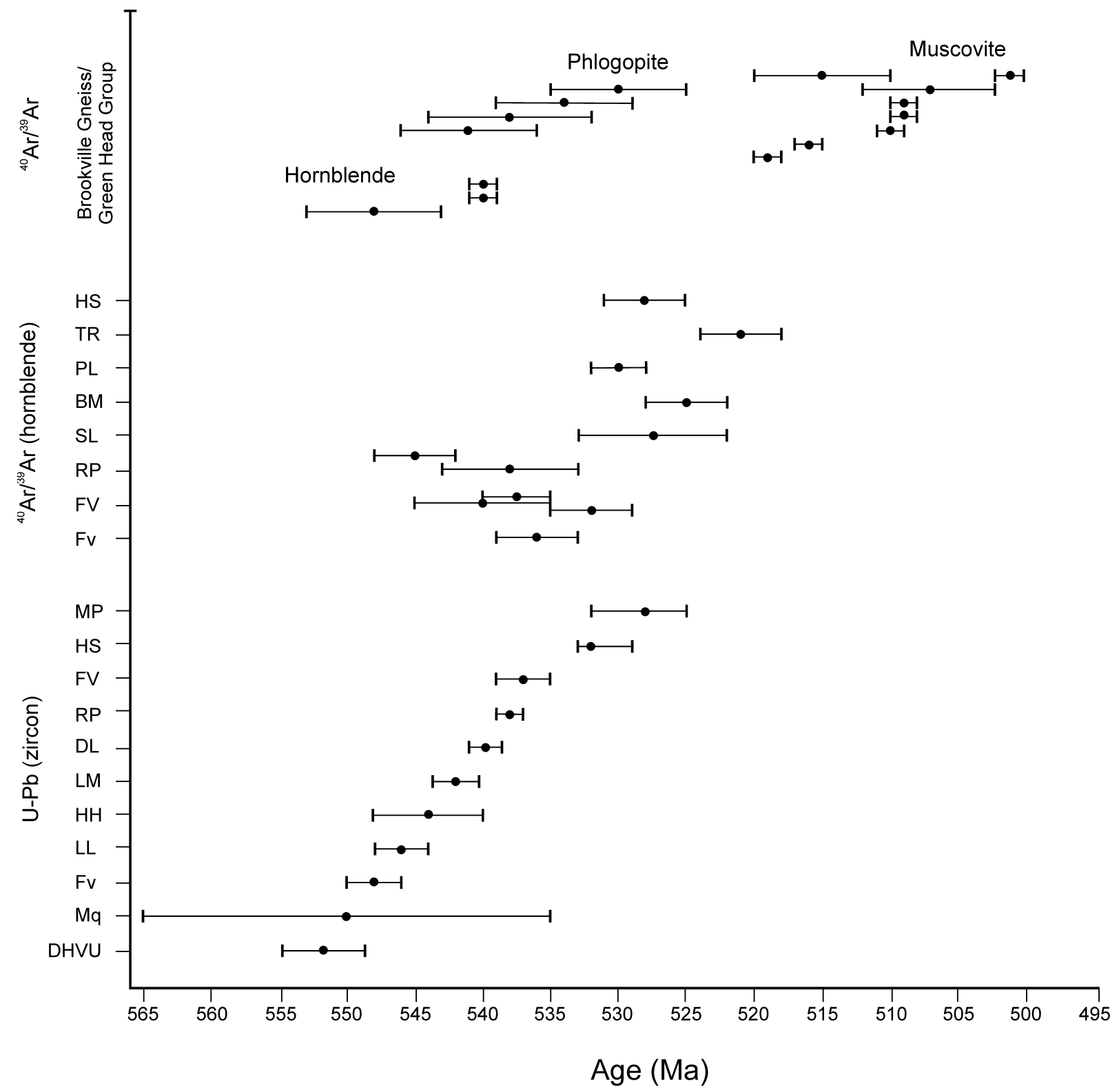

FIG. 10 Histogram of U-Pb and ${ }^{40} A r{ }^{\beta 9} A r$ ages from plutons and their host rocks in the Brookville terrane. Abbreviations: BM, Belmont Tonalite; BVG, Brookville Gneiss; DHVU, Dipper Harbour volcanic unit;DL, Duck Lake Pluton; FG, Fairville Granite; FV, French Village Quartz Diorite; GHG, Green Head Group; HH, Harvey Hill Syenogranite; HS, Hanson Stream Granodiorite; LL, Ludgate Lake Granodiorite; LM, Lutes Mountain Diorite; MP, McCarthy Point Granodiorite; Mq, Musquash Harbour Pluton; PL, Perch Lake Granodiorite; RP, Rockwood Park Granodiorite; SL, Shadow Lake Granodiorite; TR, Talbot Road Granodiorite. Data were compiled from this study and Bevier et al. (1991), Currie and Hunt (1991), Currie and McNicoll (1999), Dallmeyer and Nance (1992), Dallmeyer et al. (1990), Nance and Dallmeyer (1994), White (1996), and White et al.(1990).

\section{REFERENCES}

Abdel-Rahman, A.M. 1994. Nature of biotites from alkaline, calc-alkaline, and peraluminous magmas. Journal of Petrology, 35, pp. 525-541.

Barbarin, B., \& Didier, J. 1992. Genesis and evolution of mafic microgranular enclaves through various types of interaction between coexisting felsic and mafic magmas. Transactions of the Royal Society of Edinburgh: Earth Sciences, 83, pp. 145-153.

BARR, S.M., \& White, C.E. 1996. Contrasts in late Precambrian - early Paleozoic tectonothermal history between Avalon Composite Terrane sensu stricto and other peri-Gondwanan terranes in southern New Brunswick and Cape Breton Island, Canada. In Avalonian and related peri-Gondwanan terranes of the Circum-North Atlantic. Edited by R.D. Nance and M.D. 
Thompson. Geological Society of America Special Paper 304, p. 95-108.

BARR, S.M., \& White, C.E. 1999. Field relations, petrology, and structure of Neoproterozoic rocks in the Caledonian Highlands, southern New Brunswick, Canada. Geological Survey of Canada Bulletin 530, $101 \mathrm{p}$.

BARr, S.M., \& White, C.E. 2001. Bedrock Geology maps of parts of southern New Brunswick. New Brunswick Department of Natural Resources and Energy, Minerals and Energy Division, Open File Maps MP2001-30 to 45, scale 1:20,000 (15 maps).

Barr, S.M., Hamilton, M.A., White, C.E., \& Samson, S.D. 2000. A Late Neoproterozoic age for the Caledonia Mountain Pluton, a high Ti-V layered gabbro in the Caledonia (Avalon) terrane, southern New Brunswick. Atlantic Geology, 36, pp. 157-166.

BarR, S.M., White, C.E., \& Miller, B.V., 2001. Cambrian granitoid plutons of the Pocologan area and the continuation of the Brookville terrane to the Wolves Islands. In Current Research 2000. Edited by B.M.W. Carroll. New Brunswick Department of Natural Resources and Energy, Minerals and Energy Division, Mineral Resource Report 2001-4, pp. 15-24.

Barr, S., Fyffe, L., King, S., Mclaughlin, K., Mcleod, M., Thompson, M., \& White, C. 2002a. New U-Pb zircon ages, geophysical compilations, and terranes in southern New Brunswick. In Abstracts, 2002: 27th Annual Review of Activities. Edited by B.M.W. Carroll. New Brunswick Department of Natural Resources and Energy, Minerals, Policy and Planning Division, Information Circular 2002-1, pp. 3-4.

Barr, S.M., White, C.E., \& Hamilton, M. A., 2002b. Middle Devonian quartz monzonite from Gaytons quarry and Lower Coverdale drill core, Moncton area, New Brunswick. In Current Research 2001. Edited by B.M.W. Carroll. New Brunswick Department of Natural Resources and Energy, Minerals, Policy, and Planning Division, Mineral Resource Report 2002-4, pp. 1-10.

Barr, S.M., White, C.E., \& Miller, B.V. 2002c. The Kingston terrane, southern New Brunswick, Canada: evidence for a Silurian volcanic arc. Geological Society of America Bulletin, v. 114, pp. 964-982.

Barr, S.M., White, C.E., Venugopal, D.V., Hamilton, M.A., AND STIRLing, J.A.R. 2002d. Petrology and age of the Lower Coverdale high-Ti, - $\mathrm{P}$, and $-\mathrm{V}$ gabbro-anorthosite complex and associated granite, Moncton area, New Brunswick. Atlantic Geology, 38, p. 76.

Bevier, M.L., White, C.E., \& Barr, S.M. 1990. Late Precambrian U-Pb ages for the Brookville Gneiss, southern New Brunswick. Journal of Geology, 98, pp. 955-965.

Bevier, M.L., White, C.E., \& BarR, S.M. 1991. A new U-Pb date for the French Village quartz diorite, Saint John County, southern New Brunswick. In Project Summaries for 1991. Edited by S.A. Abbott. Sixteenth Annual Review of Activities. New Brunswick Department of Natural Resources and Energy, Minerals and Energy Division, Information Circular 91-2, pp. 195-198.

Currie, K.L. 1988. The western end of the Avalon zone in southern New Brunswick. Maritime Sediments and Atlantic Geology, 24, pp. 339-352.

Currie, K.L., \& Hunt, P.A. 1991. Late Precambrian activity near Saint John, New Brunswick. In Radiogenic age and isotopic studies: Report 4. Geological Survey of Canada, Paper 90-2, pp. 11-17.

Currie, K.L., \& McNicoll, V.J. 1999. New data on the age and geographic distribution of Neoproterozoic plutons near Saint John, New Brunswick. Atlantic Geology, 35, pp. 157-166.

Dallmeyer, R.D., \& Nance, R.D. 1992. Tectonic implications of ${ }^{40} \mathrm{Ar} /{ }^{39} \mathrm{Ar}$ mineral ages from late Precambrian-Cambrian plutons, Avalon composite terrane, southern New Brunswick. Canadian Journal of Earth Sciences, 29, pp. 2445-2462.

Dallmeyer, R.D., Doig, R., Nance, R.D., \& Murphy, J.B. 1990. 40Ar/39Ar and U-Pb mineral ages from the Brookville Gneiss and Green Head Group: implications for terrane analysis and evolution of Avalonian "basement" in southern New Brunswick. Atlantic Geology, 26, pp. 247-257.

EвY, G.N., \& CuRrie, K.L. 1996. Geochemistry of the granitoid plutons of the Brookville terrane, Saint John, New Brunswick, and implications for development of the Avalon Zone. Atlantic Geology, 32, pp. 247-268.

GorTon, M.P., \& SCHANDL, E.S. 2000. From continents to island arcs: a geochemical index of tectonic setting for arc-related and within-plate felsic to intermediate volcanic rocks. Canadian Mineralogist, 38, pp.1065-1073.

Grammatikopoulos, A. 1992. Petrogenesis, age, and economic potential of gabbroic plutons in the Avalon terrane in southern New Brunswick and southeastern Cape Breton Island. Unpublished MSc. Thesis, Acadia University, Wolfville, Nova Scotia, $378 \mathrm{p}$.

Hayes, A.O., \& Howell, B.F. 1937. Geology of Saint John, New Brunswick. Geological Society of America, Special Paper No. $5,146 \mathrm{p}$.

Hofmann, H.J. 1974. The stromatolite Archaeozoon acadiense from the Proterozoic Green Head Group of Saint John, New Brunswick. Canadian Journal of Earth Sciences, 11, pp. 1098-1115.

IRvine, T.N., \& BARAGAR, W.R.A. 1971. A guide to the chemical classification of the common volcanic rocks. Canadian Journal of Earth Sciences, 8, pp. 523-548.

Keppie, J.D., Dostal, J., Dallmeyer, R.D., \& Doig, R. 2000. Superposed Neoproterozoic and Silurian magmatic arcs in central Cape Breton Island, Canada: geochemical and geochronological constraints. Geological Magazine, 137, pp. 137-153.

Longerich, H., Jenner, G.A., Fryer, B.J., \& Jackson, S.E. 1990. Inductively coupled plasma- mass spectrometric analysis of geochemical samples. A critical evaluation based on case studies: Chemical Geology, 83, pp. 105-118.

LUDWIG, K.R. 1989. Pb-Dat: a computer program for processing raw $\mathrm{Pb}-\mathrm{U}-\mathrm{Th}$ isotope data. United States Geological Survey Open File Report No. 88-557.

McDougall, I., \& Harrison, T.M. 1988. Geochronology and thermochronology by the ${ }^{40} \mathrm{Ar} /{ }^{39} \mathrm{Ar}$ method. Oxford University Press, New York, New York. 212 p. 
Middlemost, E.A.K.1975. The basalt clan. Earth Science Reviews, 11, pp. 337-364.

NANCE, R.D. 1987. Dextral transpression and Late Carboniferous sedimentation in the Fundy Coastal Zone of southern New Brunswick. In Sedimentary Basins and Basin-Forming Mechanisms. Edited by C. Beaumont and A.J. Tankard. Canadian Society of Petroleum Geologists, Memoir 12, pp. 363-377.

Nance, R.D., \& Dallmeyer, R.D. 1994. Structural and ${ }^{40} \mathrm{Ar} /$ ${ }^{39} \mathrm{Ar}$ mineral age constraints for the tectonothermal evolution of the Green Head Group and Brookville Gneiss, southern New Brunswick, Canada: implications for the configuration of the Avalon composite terrane. Geological Journal, 29, pp. 293-322.

Park, A.F., Williams, P.F., Ralser, S., \& Leger, A. 1994. Geometry and kinematics of a major crustal shear zone segment in the Appalachians of southern New Brunswick. Canadian Journal of Earth Sciences, 31, pp. 1523-1535.

Pearce, J.A. 1982. Trace element characteristics of lavas from destructive plate boundaries. In Andesites. Edited by R.S.Thorpe. John Wiley and Sons, New York, pp. 525-548.

Pearce, J.A., Harris, N.B., \& Tindle, A.G. 1984. Trace element discrimination diagrams for the tectonic interpretation of granitic rocks. Journal of Petrology, 25, pp. 956-983.

Pitcher, W.S. 1994. The nature and origin of granite. Blackie Academic and Profession, London, UK, $321 \mathrm{p}$.

Ratajeski, K., Glazner, A.F., \& Miller, B.V., 2001, Geology and geochemistry of mafic to felsic plutonic rocks in the Cretaceous intrusive suite of Yosemite Valley, California. Geological Society of America Bulletin, 113, pp.1486-1502.

Ruitenberg, A.A., Giles, P.S., Venugopal, D.V., Buttimer, S.M., McCutcheon, S.R., \& Chandra, J. 1979. Geology and Mineral Deposits, Caledonia area. New Brunswick. Department of Natural Resources, Mineral Resources Branch, Memoir 1, $213 \mathrm{p}$.

SNEe, L.W., SutTer, J.F., \& KeLly, W.C. 1988. Thermochronol- ogy of economic mineral deposits: dating the stages of mineralization at Panasqueira, Portugal, by high-precision ${ }^{40} \mathrm{Ar} /{ }^{39} \mathrm{Ar}$ age spectrum techniques on muscovite. Economic Geology, 83, pp. 335-354.

Sun, S.S., \& McDonough, W.F. 1989. Chemical and isotopic systematics of oceanic basalts: implications for mantle composition and processes. In Magmatism in the ocean basins. Edited by A.D. Saunders and M.J. Norry. Geological Society Special Publication, 42, pp. 313-345.

West, D.P., JR., Ludman, A., \& Lux, D.R. 1992. Silurian age for the Pocomoonshine gabbro-diorite, southeastern Maine, and its regional tectonic implications. American Journal of Science, 292, pp. 253-273.

Whalen, J.B., Currie, K.L., \& Chappell, B.W. 1987. A-type granites: geochemical characteristics, discrimination and petrogenesis. Contributions to Mineralogy and Petrology, 95, pp. 407-419.

White, C.E. 1996. Geology, geochronology, and tectonic evolution of the Brookville terrane, southern New Brunswick. Unpublished PhD thesis, Dalhousie University, Halifax, Nova Scotia, $513 \mathrm{p}$.

White, C.E., \& BARr, S.M. 1996. Geology of the Brookville terrane, southern New Brunswick, Canada. In Avalonian and related peri-Gondwanan terranes of the Circum-North Atlantic. Edited by R.D. Nance and M.D. Thompson. Geological Society of America Special Paper 304, pp. 95-108.

White, C.E., Barr, S.M., Bevier, M.L., \& Deveau, K.A. 1990. Field relations, composition, and age of plutonic units in the Saint John area of southern New Brunswick. Atlantic Geology, 26, pp. 259-270.

Zain Eldeen, U. 1991. The geology of the Dipper Harbour area, southern New Brunswick, Canada. Unpublished MSc. Thesis, Ohio University, Athens, Ohio, 151 p.

Editorial responsibility: Robert A. Fensome 